\title{
The empire strikes back: the evolution of the Eastern bloc from a Soviet asset to a Soviet liability Valerie Bunce
}

A socialist system "only works if state control over the surplus is accepted by society."

"From the economic standpoint, the late capitalist grouping can renounce its former 'rollback' policy, since our bloc is ... being integrated into the unitary world market which they dominate."

The highly asymmetric distribution of resources among and within states in the Soviet bloc suggests that this empire, in direct contrast to empires of the past, should work to the clear economic and political benefit of the imperial power. ${ }^{3}$ Few colonial powers in history, for example, have been able like the Soviets to insulate their colonies from both foreign and domestic competition over economic resources and political authority. Moreover, few imperial powers in history have been so able to ensure colonial compliance with imperial demands. The Soviets can wield the stick of imperial monopoly over all the vital economic and political resources within the empire. They can also offer the carrot of a regional system that manages to forge a mutually

This article is a revised version of "The Divergence between Economics and Empire: Changing Center-Periphery Relations in the Soviet Bloc," a paper presented at the Midwest Political Science Association meeting in Milwaukee, Wisconsin, 30 April 1982. I thank in particular Bruce Moon and also Zvi Gitelman, Alex Hicks, Branko Horvat, Peter Katzenstein, Charles Lipson, Michael Marrese, the peace studies seminar at Cornell University, and five reviewers for their comments on earlier drafts.

1. Samir Amin, Unequal Development (New York: Monthly Review Press, 1976), p. 372.

2. Rudolf Bahro, The Alternative in Eastern Europe (London: NLB, 1978), p. 237.

3. The term empire is used here, because the nature of Soviet dominance over Eastern Europe-that is, the primary motives behind Soviet control, the structure of the bloc, and the distribution of resources within the bloc-is in many (but hardly all) respects similar to the nature of empires. See, for example, Robert Gilpin, War and Change in World Politics (New York: Cambridge University Press, 1981), pp. 110-15, 139-40, and Daniel Chirot and Thomas Hall, "World-System Theory," Annual Review of Sociology 8 (1982), pp. 81-106.

International Organization 39, 1, Winter $1985 \quad 0020-8183 / 85 / 010001-46 \$ \$ 1.50$

(C) 1985 by the Massachusetts Institute of Technology and the World Peace Foundation 
beneficial relationship between powerful elites in the center and powerful but dependent elites in the periphery. Finally, ease of imperial control is combined in this case with unusually sizable advantages to be gained from control. While most territories in history have been annexed to serve either economic or geopolitical interests, Eastern Europe has managed to serve both. It generates a sizable and easily transferred social surplus, and it enhances Soviet national security through partial socialist encirclement. Eastern Europe, therefore, would appear to be that rare example of an ideal colony, eminently worthy of, and highly amenable to, imperial exploitation. ${ }^{4}$

Appearances, however, are deceiving. The ledger of Soviet-bloc relations in the postwar period indicates a decline over time in the political and especially the economic value of Eastern Europe to the Soviet Union. Indeed, by the early 1980 s this seemingly ideal empire appeared to have become, in many respects, a serious burden on the Soviet Union.

The purpose of this article is to resolve the paradox between what on the one hand would appear to be ample resources available to the Soviet Union to get what it wants from control over Eastern Europe and the reality, on the other hand, of declining returns over time. I specify at the outset what would from the Soviet perspective constitute an ideal empire. I then demonstrate that Soviet gains from control over Eastern Europe have deviated more and more from this ideal since 1945. I go on to explain the declining worth of Eastern Europe to the Soviet Union as a function of an interaction among domestic, regional, and global factors. More specifically, I argue that in the mid-1950s pressures began to grow within Eastern European states to maintain rapid economic growth, yet expand public consumption. These pressures on the client states were in effect passed on to the Soviet Union by virtue of the Soviet monopoly over economic resources and political authority within the bloc.

By the late 1960s these pressures in Eastern Europe and their costs to the regional hegemon led the Eastern European elites and their Soviet patrons to converge on a decision to solve their problems by reentering the global capitalist system. Rather than solving their problems, however, the decision to terminate regional autarchy exacerbated the problems the policy was meant to counter and, indeed, created some new ones. As the states of Eastern Europe became more dependent on the West for markets and capital during the 1970s, so they became even more dependent on the Soviet Union for the same. In this sense it can be concluded that the empire in Eastern Europe "struck back" for two related reasons. First, the Soviet Union was in effect "hoist by her own petard," that is, by the accumulated costs associated with dominance over a region composed of derivative and highly dependent Stalinist political economies. Second, the Soviets were hoist by the petard of late capitalism, that is, by the pressures Western trade placed on command 
economies, by the need of Western banks to recycle petrodollars in the 1970s, and by the global recessions of 1973-74 and 1979-82.

\section{The ideal empire}

In order to assess changes over time in how valuable Eastern Europe has been to the Soviet Union, we need a standard for evaluation. This standard must be as objective as possible, must be applicable to the bloc over the entire postwar period, and must be sensitive to the full range of interests that might be or have been served by empire. The approach I take is to construct an ideal empire - that is, an empire that has ideal outcomes insofar as Soviet interests are concerned-and then assess the extent to which Soviet gains from Eastern Europe have conformed to these ideal outcomes.

What are Soviet interests in Eastern Europe? At the most general level, the Soviet Union wants Eastern Europe for the same reasons all states want colonies. Acquisition of outside territory helps the state maximize national security, economic growth and stability, and domestic political stability. From this perspective, an ideal colony would be easy to control, cheap to administer, and highly valuable in economic and geopolitical terms. When translated into specific outcomes resonant with Soviet values and interests, the Soviets' ideal empire should accomplish ten tasks. First, with regard to national security, Eastern Europe should behave as a reliable ally, should contribute to the Soviet and regional defense burden, and should enhance Soviet power in the international system. Second, with respect to economic interests, Eastern Europe should be relatively cheap to administer and yet at the same time provide the Soviet Union with greater economic stability through assured, stable, and malleable markets and through a growing and easily transferred surplus; needed primary and secondary products at low cost; and favorable terms of trade. Finally, with respect to domestic stability, the empire in Eastern Europe should be seen by the Soviet population and dominant interests within that system as an asset; it should provide an added barrier to any external influences that might in a hostile international system challenge domestic stability or undercut the domestic control exercised by the Soviet state; and it should help dampen conflict among powerful interests within the Soviet Union by achieving the goals noted above, thereby easing the Soviet state's task of allocating money, power, and privilege at home.

To what degree has Soviet dominance over Eastern Europe managed to accomplish these objectives? I approach this issue by assessing the extent to which these ideal outcomes were achieved in the Stalinist period (1945-53), the Khrushchev period (1953-64), and the Brezhnev era (1964-82). As we shall discover, Soviet returns from empire were remarkably close to the ideal during the Stalinist period. By the end of the Brezhnev era, however, it could be concluded that control over Eastern Europe was meeting only one of the 
three sets of objectives: the maximization of Soviet national security. And even in this sphere it could be argued that the outcome was less favorable than in the past, since security was purchased at a much higher cost.

\section{The Stalinist period: an ideal empire}

Most empires in history have featured a mix of assets and liabilities insofar as imperial interests were concerned. One major reason is that the various goals of empire often dictate policies that are inherently contradictory. For example, there are inherent tensions between exerting maximum political control over colonies, in order to ensure the generation and easy transfer of capital, and the burdensome administrative and military responsibilities such control generates. There is also a tension between acquiring colonies that are attractive in economic and geopolitical terms and, as a result of their worth, having to deal with competitors for political power and the social surplus. Finally, there is a logic in maintaining local power structures in the colonies, as a way of minimizing disruptions and discontent; yet the very fact of indirect rule places coopted elites in a position of power that over the long run will lead to a diversion of capital into local coffers and, more generally, decreasing compliance with the demands of the center.

Imperial powers, therefore, usually have to make hard choices among goals. Indeed, it is difficult to imagine an empire that maximizes national security and access to a sizable surplus while simultaneously keeping administrative and military costs to a minimum.

The Soviet bloc during the Stalinist period seemed to accomplish all of these seemingly contradictory objectives. The bloc was unique in its domestic and regional structure, unique in its relationship to the international system, and unique, as a result, in its capacity to maximize the imperial power's domestic and foreign interests. More specifically, the empire in Eastern Europe had three characteristics: Stalinism in the domestic sphere; complete Soviet control over the borders of the system and over the primarily bilateral interactions between states within the region; and isolation of the region from the international system. As a result, client states within the bloc depended on the Soviet Union for political power, economic stability, and economic growth.

The recreation of the Stalinist experience in Eastern Europe was a twostage process, which took place from approximately 1945 to 1953 . The first stage involved the destruction of the old system. Much had been accomplished by the bitter interwar experience and the war itself, especially in Yugoslavia, Hungary, and Poland. The destruction was completed by Soviet occupation, the assignment of Eastern Europe to the Soviet zone of influence, the use by Communist parties of popular appeals including calls for land reform and punishment of fascist collaborators, and the discrediting by wartime and 
interwar experience of alternative elites, governing parties, and governing formulas. The second stage involved the creation of a new political economy that adhered closely to the Stalinist model. On the economic side, the new system included the introduction of state ownership of the means of production, central planning, collectivization of agriculture, and rapid industrialization both through controlled consumption and through the funneling of considerable forced savings into heavy industry. On the political side, Stalinism involved the concentration of resources in the hands of an authoritarian party and the use of terror to destroy old allegiances and power structures, force allegiance to the new order, and further concentrate power in the upper reaches of the party-and in particular in the hands of those trained in Moscow and obedient to Soviet wishes.

In practice Stalinization meant, as in the Soviet experience, that the familiar boundaries separating the polity, the economy, and the society in most systems were nonexistent. Instead, political, economic, and social arenas, roles, and resources were interdependent and fused. ${ }^{5}$ Control over these pooled and, therefore, sizable resources, moreover, was highly concentrated at the top of the party and state hierarchies. Those elites exercised monopolistic and monopsonistic control over a rapidly expanding economy, and they had considerable incentives to maximize that growth. Fusion forged an interdependence between political fortunes and economic performance, and between control over political power and control over economic resources.

Stalinist political economies in the client states thus allowed the Soviet Union to avoid many of the common problems that have undercut the value of empires in the past. In particular, the Soviets avoided governance over internally weak colonial states. They sidestepped all those considerable costs attached to choosing either cooptation or replacement of indigenous elites. And they did not face the common dilemma of having access to either unwanted goods in the colonies or, given the diffusion of power and the need to placate interests when establishing external control, a social surplus con-

5. The term fusion I use to emphasize how uniquely merged, concentrated, and interdependent resources are in a Stalinist political economy. The significance of fusion for the role of the state and the structure of conflict in Eastern Europe will be assessed below. For assessments of how the structure of the Stalinist political economy evolved and how fusion affects the distribution of power in these systems, see George Konrad and Ivan Szelenyi, The Intellectuals on the Road to Class Power (New York: Harcourt Brace Jovanovich, 1979), especially pp. 147-48; HansHermann Hohmann, "The State and the Economy in Eastern Europe," in J. E. S. Hayward and R. N. Berki, eds., State and Society in Contemporary Europe (New York: St. Martin's, 1978), pp. 141-57; Mihaly Vajda, The State and Socialism (New York: St. Martin's, 1981), p. 135; and Alec Nove, "Socialism, Centralized Planning and the One Party State," in T. H. Rigby, Archie Brown, and Peter Reddaway, eds., Authority, Power and Policy in the USSR (New York: St. Martin's, 1980), pp. 77-97. Fusion should not be confused with corporatism, since the latter implies, particularly in its liberal variant, some separation of arenas and a state that has some autonomy. For further discussion of both terms and their application to the contemporary Soviet case, see Valerie Bunce, "The Political Economy of the Brezhnev Era: The Rise and Fall of Corporatism," British Journal of Political Science 13 (January 1983), pp. 129-58. 
strained by far too many claimants. Instead, by establishing Stalinist systems in Eastern Europe, the Soviet Union guaranteed, at least initially, that her colonies would be stable, that their governing parties would be subject to few political or economic pressures from below, and that the economies in the client states would grow and grow in an optimal way.

The impressive array of resources available to the party elite in Eastern Europe and the Stalinist expansion of those resources, however, did not lead to the seemingly logical outcome. Eastern European party elites did not grow more autonomous. Instead, in expanding the resource base of colonialized elites, the Soviet Union in fact expanded her own control over resources throughout the bloc. The symmetry at the time between Eastern European elite and Soviet elite interests helps explain this historically peculiar outcome; so does the political and economic dependence of Eastern European elites on the Soviet Union.

That political dependence had four main components. The first was the minimal domestic mandate of many of these parties as a result of Soviet "liberation" (especially in the cases of Poland, Hungary, Romania, and the GDR ). ${ }^{6}$ The second was the role of the Soviet Union in either creating these Communist parties (as in Romania and the GDR) or in effect recreating them (as in Poland and Hungary). The third was the Soviet demonstration in 1948 that Moscow controlled leadership selection in Eastern Europe and in all cases preferred Moscow-trained Communists over indigenous elites. The fourth consideration was the role of the Soviet Union as hegemon within a closed regional system, which, given bipolarity in the international system and the structure of the bloc, was left outside the zone of Western intervention and, as the Czechoslovak crisis with respect to the Marshall Plan indicated, Western aid as well. The considerable power of Eastern European elites, made possible by Stalinism, was in reality, to use Wladyslaw Gomulka's apt phrase, "a reflected brilliance, a borrowed light."" The power of these elites was derivative and dependent.

The states of Eastern Europe were also economically dependent on the Soviet Union. Wartime destruction had been particularly great in Poland, Hungary, and Yugoslavia. East European economies were generally small,

6. The Hungarian case suggests that public consensus on the need for revolutionary change was sizable. What was at considerable issue, however, was Soviet domination. See Charles Gati, "Modernization and Communist Power in Hungary," East European Quarterly, September 1971.

7. Quoted in Christopher Jones, Soviet Influence in Eastern Europe: Political Autonomy and the Warsaw Pact (New York: Praeger, 1981), p. 7; see also pp. 2-23. For analyses that assert, in contrast to Jones, that the domestic structure of Eastern Europe and the structure of the bloc had less to do with pressures imposed by Soviet expansionism than with necessary actions arising from Soviet concerns with limiting the influence of capitalism and thereby preserving the Soviet state, see Christopher Chase-Dunn, "Introduction," in Chase-Dunn, ed., Socialist States in the World System (Beverly Hills: Sage, 1982), pp. 9-18; David Ost, "Socialist World Market as Strategy for Ascent?" in Edward Friedman, ed., Ascent and Decline in the World System (Beverly Hills: Sage, 1982), pp. 229-54. 
had a limited industrial base (except in Czechoslovakia), and were weak in primary products; the Soviet economy, by comparison, was large and had a considerable resource base. Finally, the Soviet Union could exert control over the region, because the Soviets controlled the primarily bilateral political and economic transactions within the region and the primary products necessary for industrialization.

The Soviets, therefore, had ample control over both the powerful elites and the expanding economies they had in effect created in the client states. Eastern European elites acted as willing and capable transmission belts, maximizing Soviet foreign and domestic interests. The Soviets gained all the benefits of partial socialist encirclement, including greater security from the West and greater control over the domestic population. In the immediate postwar period they also received capital from the client states of an amount roughly equal to what the United States transferred to Western Europe through the Marshall Plan. ${ }^{8}$

What made these arrangements particularly successful was that Soviet gains were in many respects Eastern European gains as well. The reproduction of the autarchic Soviet model, the decision by Stalin to maintain separate states and separate economies in the bloc, and the decision to continue the prewar Soviet practice of autarchic development, all indicated that Soviet interests in the area were primarily related to national security. The elites in Eastern Europe had in fact a great deal of control over their own economies, especially after the Soviets completed postwar reconstruction. Eastern European elites had opportunities to retain much of the surplus and to use the economy as a major mechanism for expanding their political power at home.

Fusion, rapid industrialization, and incorporation into a regional system also provided some concrete payoffs, among them a sense of national security, the proliferation of groups and individuals who benefited from rapid growth and one-party control, and protection from Western business cycles for a region severely affected by those cycles before 1939 . Stalinism also brought some relief from the negative effects, so acutely felt during the interwar period, of Eastern Europe's primary-product dependence, its small domestic markets, and the typical combination of too many intellectuals with too little economic growth. ${ }^{9}$ Indeed, as George Konrad and Ivan Szelenyi have argued,

8. See Paul Marer, "Has Eastern Europe Become a Liability to the Soviet Union: (II) The Economic Aspect," in Charles Gati, ed., The International Politics of Eastern Europe (New York: Praeger, 1976), pp. 59-81. Also see Marer, "The Political Economy of Soviet Relations with Eastern Europe," in Steven J. Rosen and James R. Kurth, eds., Testing Theories of Economic Imperialism (Lexington: Heath, 1974), pp. 231-60.

9. See Wlodzimierz Brus, "Stalinism and the 'Peoples' Democracies," in Robert Tucker, ed., Stalinism (New York: Norton, 1977), pp. 239-56; Paul Johnson, "Changing Social Structure and the Political Role of Manual Workers," in Jan Triska and Charles Gati, eds., Blue Collar Workers in Eastern Europe (London: Allen \& Unwin, 1981), pp. 29-42, especially pp. 34-36; Andrew C. Janos, "The One Party State and Social Mobilization: East Europe between the Wars," in Samuel Huntington and Clement Moore, eds., Authoritarian Politics in Modern Society (New York: Basic Books, 1970), pp. 204-36; and Bahro, The Alternative in Eastern Europe, pp. 117-19. 
the rapid expansion of power and resources during the Stalinist period gave the intelligentsia in Eastern Europe the role they had always sought-teleological power brokers-and the system they had always wanted-rational redistribution. ${ }^{10}$

Finally, these structural arrangements provided a means for linking these fractious societies to a new and more coherent political order. For example, the Stalinist stage saw a tremendous expansion of powerful positions in the Party and in the economy, as one might expect in a command economy controlled by an authoritarian party and bent on rapid industrialization. For the citizenry as a whole, moreover, the compression of the modernization experience brought enhanced opportunities for upward political and social mobility. ${ }^{11}$ Attachments were forged through the exhilarating experience of participating in the creation of a new society characterized by an expanding social wage, job security, and rapid socioeconomic transformation. Finally, in an area long the typical periphery, whose countries had functioned as the pawns of global powers because of an unfortunately strategic geopolitical location, Stalinism allowed for the possibility of achieving "national mobility" as well. ${ }^{12}$ Stalinism created, in short, many vested interests. While Stalinism had its costs to the coopted elites in Eastern Europe, these costs were not so large when viewed from the perspective of the turbulent interwar period.

From the Soviet perspective, of course, the costs were even smaller and the gains even more significant. Eastern Europe was an important counterweight to the West, and Soviet borders were secure as never before. The bloc's compliance with Soviet concerns was high and at a low cost. And the colonies were essentially self-supporting, deficient only in areas of Soviet largesse: primary products and political power. Eastern Europe at this time, then, was an ideal empire, easy to control and highly valuable in economic, political, and national security terms.

\section{Some deviations from the ideal: 1953-64}

The impact of Stalin's death in 1953 demonstrated that certain preconditions had to be met if Eastern Europe was to continue functioning as an ideal empire. More specifically, the degree to which the bloc functioned as a Soviet asset depended upon four conditions: rapid economic growth in the client states such that domestic conflict could be moderated; continued Soviet

10. Konrad and Szelenyi, Intellectuals on the Road. They note, among other things, the tremendous expansion, given centralized planning and authoritarian one-party rule, of managerial positions during Stalinism.

11. Walter Connor, "Socialism, Work and Equality," in Irving Louis Horowitz, ed., Equity, Income and Policy (New York: Praeger, 1977).

12. Christopher Chase-Dunn, "Socialist States in the Capitalist World Economy," Social Problems 27 (June 1980), p. 515. 
control over world communism and, hence, continued unity and obedience within the bloc; continued ability of Eastern European parties to maintain absolute control over their societies and their economies such that the parties functioned as both powerful political and economic monopolies at home and dependent and obedient allies abroad; and a continued congruence between the political interests of Soviet and East European elites. Over the course of Khrushchev's tenure all four of these preconditions were challenged to some degree. The empire, as a result, lost some of its gloss.

The first complication grew out of Khrushchev's relations with the communist world and his encouragement, by accident and some design, of different roads to socialism. His rapprochement with Tito, for example, had the effect of weakening all the elites in Eastern Europe, since each had ridden to power on the back of the anti-Titoist purges in 1948-49. This shift also undercut to some degree the control these elites had over the working class. Their spirited attacks on Yugoslav self-management since 1948 contrasted sharply with the implication in improved Soviet-Yugoslav relations that some tolerance, albeit severely limited, of the Yugoslav model was permissible.

At the same time the increasingly deviant behavior of Albania and China, along with Soviet tolerance of deviance in Poland in 1956, indicated to the Eastern European party elites that they had some bargaining power. Indeed, if the Party maintained control (which was itself in the elites' interest), some deviance was possible especially if linked to the continuation of domestic tranquillity. This recognition was particularly pronounced in those states which were close to the Soviet border yet which had weak governing mandates and limited legitimacy. Romania and Poland, for example, needed to put a distinctive stamp on their roads to socialism. ${ }^{13}$

De-Stalinization, however, made control over domestic populations in the periphery ever more difficult. One can debate at length about whether deStalinization was an accidental by-product of the Soviet succession struggle in a regional system where dissent as well as power flow westward, or a ploy by Khrushchev to gain control over the satellites by installing his own men into power, or a conscious decision reflecting Khrushchev's genuine aversion to Stalinist excesses and his commitment to stimulating a moribund system

13. See William Zimmerman, "Hierarchical Regional Systems and the Politics of System Boundaries" International Organization 26 (Winter 1972), pp. 18-36; Kenneth Jowitt; The Leninist Response to National Dependency (Berkeley: University of California, Institute of International Studies, 1978); Kenneth Jowitt, "The Romanian Communist Party and the World Socialist System: A Redefinition of Unity," World Politics 23 (October 1970), pp. 38-60; Chris Jones, "Soviet Hegemony in Eastern Europe: The Dynamics of Political Autonomy and Military Intervention," World Politics 29 (January 1977), pp. 217-41; Cal Clark, “The Evolving Nature of Hierarchy in the Soviet-East European International System" (paper presented at the annual meeting of the American Political Science Association, Chicago, 2-4 September 1983); and Clark and Donna Bahry, "Dependent Development: A Socialist Variant," International Studies Quarterly 27 (September 1983), pp. 271-94. 
through populist principles and a shift from power to authority. ${ }^{14}$ What is not debatable is that what happened in Hungary from 1953 to 1956 , the German Democratic Republic and Czechoslovakia in 1953, and in Poland once Boleslaw Bierut, the head of the Party, died, placed elites in all of the client states in a vulnerable position. They had been installed by and were beholden to Stalin. They had forced (especially in Hungary) tremendous social sacrifices in a very short period of time in the name of Stalin. They headed historically fractious, rapidly changing, and very new societies, which were the creation not of domestic Communist parties so much as interwar turmoil, the war itself, and the Red Army. Moreover, in Hungary and to a lesser extent Poland, Czechoslovakia, and Romania, terror against the Party had nearly equaled the Soviet experience of the 1930s, but it had happened in new societies of more recent but equally revolutionary vintage and through a process telescoped into a few short years. Indeed, in the Polish case the Party had been purged three times-during the 1930s, during the Soviet occupation, and during the anti-Titoist purges. Finally, in the more developed economies in the north, elites faced slower growth. Given fusion between the polity and the economy, this slowdown exacerbated intraparty conflict, especially when combined with an ongoing succession crisis as in Hungary, Poland, and Czechoslovakia. In the Hungarian case, in particular, Khrushchev's juggling of Rakosi and Nagy mobilized competitive groups within the Party, replacing the consensual and authoritarian one-party control so necessary for domestic stability.

As a result, de-Stalinization in Eastern Europe was a dramatic and difficult break with a past that was not as institutionalized nor as resonant with historical traditions in the Soviet experience. It was also a break made easier by remnants of elites and ideologies from the past, remnants long gone from the Soviet scene by 1956 . The impact of de-Stalinization was, not surprisingly, greatest in those systems which combined in extreme form all of the factors noted above - in particular, Hungary, Poland, and eventually Czechoslovakia. In these states de-Stalinization translated (with some ease, given fusion and intraparty conflict) into demands by intellectuals and, to a lesser degree, workers for a new leadership (especially in Poland) and substantial political and economic reforms (especially in Hungary). All three countries demanded immediate economic recompense, so long promised, for the sacrifices made during the brief Stalinist industrialization drive. Elites in Bulgaria, Romania, Albania, and Czechoslovakia managed to put off reforms until the invasion of Hungary sealed the fate of many of these measures. But the impact of reforms elsewhere was dramatic: for a brief period, domestic politics reappeared in the periphery.

14. Compare, for example, Jones, Soviet Influence, p. 8, with Jeremy Azrael, "Varieties of De-Stalinization," in Chalmers Johnson, ed., Change in Communist Systems (Stanford: Stanford University Press, 1970), pp. 135-52; and with George Breslauer, Kruschchev and Brezhnev as Leaders: Building Authority in Soviet Politics (London: Allen \& Unwin, 1982), pp. 23-60. 
Domestic demands strained both elites and empire. Within the periphery they by definition implied a dispersion of the Party's monopoly over political and economic resources, a monopoly essential to the continued stability of these systems and to their role as transmission belts for Soviet interests. Indeed, Eastern European elites were caught between their longer-term interests (and the interests of the Soviet Union) and the immediate concerns of their various publics. Domestic demands - direct in some cases, feared in others-implied dispersion of political and economic power through an opening up of the Party, decentralization of the economy, the establishment of "national communism," and increased emphasis on domestic consumption over capital investment. ${ }^{15}$

The elites' dilemma, in brief, was that their long-term needs for rapid growth and Party control were inconsistent with short-term political pressures from below. The resolution they chose was to shore up inroads into Eastern European (and thereby Soviet) elite control over economic and political resources in Eastern Europe while ameliorating mass discontent in ways that would not threaten the highly skewed distribution of political and economic power at home and within the bloc. ${ }^{16}$ Serious reform in the aftermath of Poland and Hungary in 1956, therefore, was rejected in favor of retracting the worst abuses of Stalinism, particularly insofar as terror against the Party was concerned. Symbols of reform were provided, either through the inauguration of new leaders who had suffered under Stalin (Gomulka in Poland, Kádár in Hungary) or through decollectivization (in the Polish case). In the short term public consumption was primed. To have responded in any other way would have led to the dismantling of the whole system, since the forfeiture by the Party of either economic or political power would have been the forfeiture of both. It would also mean the forfeiture of Soviet dominance over the region.

The fiscal burden of these decisions seems to have fallen primarily on Soviet shoulders. It did so, ironically, because of Soviet power and Eastern European weakness. Soviet strength involved Soviet monopoly over all the fiscal, political, and military resources necessary for purchasing short-term stability in the bloc. The Soviets were the political patrons of domestically weak party elites in the client states; they had the liquidity-in economic as well as political terms - to get through a crisis; they were autarchic whereas Eastern Europe needed Soviet primary products in order to maintain growth; and, finally, because of bilateralism and the redundancy of Eastern European economic strengths and weaknesses, the Soviet Union was the central participant in what were at that time limited trade relations within the bloc.

15. See Jan Triska, "Workers' Assertiveness and Soviet Policy Choices," in Triska and Gati, Blue Collar Workers, pp. 268-69; Konrad and Szelenyi, Intellectuals on the Road, pp. 155-57.

16. See Valerie Bunce, "Neither Equality nor Efficiency: International and Domestic Inequalities in the Soviet Bloc," in Daniel Nelson, ed., Communism and the Politics of Inequalities (Lexington: Heath, 1983), pp. 5-34; Zvi Gitelman, "The Politics of Socialist Restoration in Hungary and Czechoslovakia," Comparative Politics 13 (January 1981), pp. 187-210. 
At the same time the Soviets had what might be called a political as well as an economic monopoly: they had unusually strong incentives to bail out Eastern European elites. The region was critical for defense, especially in the context of American economic and military superiority. Unrest "in one country" was not safe in a regional system where contiguous states were similar in their origins and political-economic arrangements. De-Stalinization and the costs of the Hungarian invasion had already limited the domestic tools available for "encouraging" public restraint.

Eastern Europe's Party elites had a very strong set of arguments in support of economic aid. Dissent could cross Soviet borders by passing through the Baltic republics and the Ukraine. Moreover, the elites could argue, decisions in such circumstances should be based on the "worst case scenario"-it was safer to assume that unrest was contagious, since to assume otherwise and be wrong would have necessarily dangerous consequences for bloc stability. Finally, there was an ideological consideration. Purchasing stability and introducing some reforms were both consonant with Khrushchev's concerns with creating a more positive basis for regime-society relations in the postStalinist period.

The weakness of Eastern European elites, which had few resources to deal with the consequences, real and feared, of de-Stalinization, thus enhanced their ability to bargain with Moscow. As a result, the Soviet Union functioned in the short term as the fiscal guarantors of political stability throughout the region. In practice, the Soviets helped pay for increases in public consumption throughout Eastern Europe during the second half of the 1950s. ${ }^{17}$ They provided relatively cheap primary products to all of Eastern Europe, allowed some deterioration between 1956 and 1964 in Soviet terms of trade within the bloc, and extended emergency and nonrepayable aid to regimes in trouble-the German Democratic Republic and Czechoslovakia in 1953, Hungary and Poland in 1956. ${ }^{18}$

Once implemented, however, Soviet aid in the form of implicit trade subsidies became standard operating procedure, and for three reasons. First, there was by the early 1960s an economic slowdown in much of Eastern Europe. ${ }^{19}$ The result was that Eastern European elites lost capacity to respond to domestic economic demands while continuing to fear that failure to respond would spark unrest, particularly in countries that had avoided de-Stalinization, such as Czechoslovakia. Indeed, every state in the bloc had some bargaining resources in regard to its demonstrated or potential vulnerability. Second, small economic subsidies were far less costly for the Soviet Union than was

17. For evidence on the linkages between the crises of 1956 and increases in public consumption in the bloc, see Frederik Pryor, Public Expenditures in Communist and Capitalist Nations (Homewood, Ill.: Dorsey, 1968).

18. Marer, "Political Economy"; Triska, "Workers' Assertiveness."

19. Jan Vanous, "East European Economic Slowdown," Problems of Communism 31 (July-August 1982), pp. 1-19. 
the risk of unrest and its threats to national security and domestic political stability. The size of the Soviet economy, its autarchic structure, and the fact that Eastern Europe's economic needs were in areas of Soviet excessthat is, primary products - all reduced potential cost. Finally, given the importance of growth for moderating the heated competition for economic and political resources, the economic downturn in Eastern Europe and rising mass expectations produced substantial political conflict within these systems, as one would expect.

The Eastern Europeans, then, had a powerful set of arguments for the continuation of favorable terms of trade. As a result, by the end of Khrushchev's tenure the empire in Eastern Europe had become less profitable for the Soviets. ${ }^{20}$ The rising costs associated with trade and periodic unrest in the periphery were, however, minimal when compared with all the assets involved. Eastern Europe provided a Soviet bridgehead in Europe, helped shoulder a defense burden that was growing rapidly in response to EastWest competition, provided the Soviet economy with some needed items, and enhanced Soviet control over their domestic population through partial socialist encirclement. This was still a lot to receive for a few rubles, especially since they seemed to produce desired ends. The bloc was, after all, stable from the late 1950s to the end of Khrushchev's tenure, despite economic slowdown during the first half of the 1960s.

\section{The empire strikes back: $1964-82$}

The Brezhnev regime tried to return intrabloc relations to their previous footing. Brezhnev wanted the bloc to continue to further Soviet foreignpolicy interests while he wanted at the same time to improve upon his predecessor's record in maximizing economic growth and political stability. He failed. By the end of Brezhnev's tenure a pattern common both to empires of the past and to military alliances had evolved. National security was purchased at higher and higher cost, both because there were tensions inherent in Soviet interests insofar as Eastern Europe was concerned and because fears of sacrificing growth and stability on the altar of national security led to decisions that, ironically, undermined all three Soviet goals.

The concern with national security led the Soviets, in the aftermath of Czechoslovakia in 1968, to tighten their control over the Warsaw Pact and over leadership selection in Eastern Europe. Demanding Eastern European help in their arms buildup, the Soviets stipulated through the Brezhnev doctrine the limits of deviance for client states in domestic and especially

20. See Marer, “Political Economy”; Marer, "Has Eastern Europe." For an assessment of Soviet costs and benefits at this time and the difficulties involved in making such assessments, see also Paul Marer, "Prospects for Economic Assistance," in Jan Triska and Paul Cocks, eds., Political Development in Eastern Europe (New York: Praeger, 1977), pp. 256-74. 
foreign-policy behavior. ${ }^{21}$ They were relatively successful. However, these achievements in national security were offset by some loss, albeit impossible to measure, of influence in the Third World as a result of the Sino-Soviet rift, the crisis in Czechoslovakia, and the Polish crises of 1970, 1975-76, and 1980-83; the Romanian deviation in foreign policy and the Albanian alliance with China; the continued thorn of Yugoslavia; a decline over time in bloc cohesion; ${ }^{22}$ and the ability of most members of the bloc during the 1970s either to reduce their defense burden (expressed as a percentage of GNP) or, as with Bulgaria and the GDR, to hold contributions to the regional defense burden relatively constant. ${ }^{23}$ While these costs were important, however, the foreign-policy benefits the Soviets reaped from empire were still sizable. Eastern Europe still carried about 10 percent of the bloc-wide defense burden, for example.

The same could not be concluded for Soviet gains from intrabloc economic relations. From 1961 to 1965 the average annual rate of growth in the Soviet GNP had slowed to 5 percent, a postwar low. ${ }^{24}$ In part this slowdown reflected the natural limits to rapid growth in a planned economy based on extensive development. In part, however, it also reflected the costs of empire: for example, the unfavorable terms of trade within the Soviet bloc, the costs of having extended aid to regimes in trouble, and the structural inability of Eastern Europe to provide the Soviet Union with needed, let alone highquality, products.

The Brezhnev regime approached these problems by instituting economic reform at home and changing economic relations abroad. The Brezhnev regime charged more for Soviet primary products, because it used five-year moving averages based on world market prices. It pressured the bloc to coordinate economic plans to a greater extent and to increase the level of capital investment. It also pressured Eastern Europe to specialize; the northern tier would focus on the production of consumer goods and machine tools,

21. Jones, Soviet Influence; William Zimmerman, "Soviet-East European Relations in the 1980's and the Changing International System," in Morris Bornstein, Zvi Gitelman, and Zimmerman, eds., East-West Relations and the Future of Eastern Europe (London: Allen \& Unwin, 1981), pp. 87-104.

22. Richard Flashkamp and Daniel Nelson, "Détente and the Warsaw Pact: East European Military Expenditures in an Era of Decreased East-West Conflict" (paper delivered at the Western Social Science Association meeting, Denver, Colorado, 12 November 1981); Zimmerman, "Soviet-East European Relations."

23. See the data reported in William M. Reisinger, "East European Military Expenditures in the 1970s: Collective Good or Bargaining Offer?" International Organization 37 (Winter 1983), pp. 147-55. For assessments of trends over time in the bloc's military outlays, see International Institute for Strategic Studies, The Military Balance, 1982-1983 (London, 1982), pp. 124-46, and Stockholm International Peace Research Institute, World Armaments and Disarmament: SIPRI Yearbook, 1983 (New York: Taylor \& Frances, 1983), p. 162.

24. This is the CIA estimate. See U.S. Congress, Joint Economic Committee (JEC), USSR: Measures of Economic Growth and Development, 1950-1980 (Washington, D.C., 8 December 1982), pp. 15-16. While Western estimates of Soviet GNP vary, the trends over time are similar from one study to the next. 
the southern tier on agriculture and the processing of raw materials. The Soviets went along with economic reforms in Hungary and the GDR, in the hope that such measures would bolster growth and improve the quality of products. Moreover, they encouraged Eastern Europe to use détente to open up trade relations with the West. Western trade would take some pressure off the Soviet economy and encourage, through the imposition of Western standards, an improvement in the quality and diversity of goods produced in the bloc.

These measures were not successful, and the economic burdens of empire increased rather than declined. Bloc specialization and plan coordination proceeded in a stop-and-start manner, because of the autarchic legacies and the vested economic and political interests generated by Stalinism. Eastern Europe also feared that a regional division of labor would make it more dependent on the Soviet Union. In practical terms, moreover, shortages of capital, weaknesses in technological innovation, the commitment to full employment, and the significant growth of the second half of the 1960s in most of Eastern Europe limited incentives for such a strategy. ${ }^{25}$ Indeed, there were few good political or economic reasons for Eastern Europe to go along with Soviet demands for major structural changes in their economies.

The biggest failure, however, was in intrabloc trade and Soviet transfers of explicit subsidies. While the Soviet terms of trade within the bloc did in fact improve over the course of the Brezhnev era, particularly during the 1970 s, the rate of improvement paled against dramatic improvements in the Soviet terms of trade with the West. ${ }^{26}$ Soviet exports to the West and to the bloc were essentially the same products and increasingly attractive in the world market. As a result, the opportunity costs attached to Soviet trade within, as opposed to outside, the bloc were substantial. Indeed, one estimate of these opportunity costs by Jan Vanous and Michael Marrese places the loss to the Soviet Union from intrabloc trade at 21.7 billion current U.S. dollars from 1974 through $1980 .{ }^{27}$ As Table 1 indicates, moreover, the Soviet Union's implicit and, it must be emphasized, nonrepayable trade subsidies to Eastern Europe rose sharply over the 1970s. The rise reflected the fact that intrabloc prices for Soviet raw materials and energy had not kept pace with world market prices and the extent to which Eastern European states had neither the economic incentives nor the structural capacity to cut back

25. Vanous, "East European Economic Slowdown." Also see JEC, USSR: Measures of Economic Growth, pp. 15-16. It is important to note that the Soviets were also ambivalent about specialization within the bloc, since such a policy would allow some states to gain added leverage through monopoly over vital products.

26. For evidence on this point, see Eleftherios Botsas, "Trade Patterns," in Stephen FischerGalati, ed., Eastern Europe in the 1980s (Boulder: Westview, 1981), p. 98; United Nations, Economic Bulletin for Europe, vol. 33 (New York, 1981), pp. 1.6, 1.14-1.18.

27. Jan Vanous and Michael Marrese, "Soviet Subsidies to Eastern Economies," Wall Street Journal, 15 January 1982; see also their Soviet Subsidization of Trade with Eastern Europe: A Soviet Perspective (Berkeley: University of California, Institute of International Studies, 1983). 
TABLE 1. Estimated implicit Soviet trade subsidies to Eastern Europe (in million current dollars) ${ }^{\mathbf{a}}$

\begin{tabular}{rrrrrrrr} 
& Bulgaria & Czechoslovakia & GDR & Hungary & Poland & Romania & Total \\
\hline 1974 & 1081 & 1174 & 2023 & 877 & 1067 & 43 & 6265 \\
1975 & 919 & 1097 & 1665 & 598 & 1027 & 19 & 5325 \\
1976 & 877 & 1195 & 1786 & 671 & 1021 & 45 & 5595 \\
1977 & 1015 & 1226 & 1896 & 645 & 1106 & 50 & 5938 \\
1978 & 1087 & 1086 & 1914 & 661 & 897 & 109 & 5754 \\
1979 & 2000 & 2000 & 3400 & 1200 & 1700 & 100 & $10,400^{\mathrm{b}}$ \\
1980 & 4100 & 4100 & 7200 & 2600 & 3500 & 200 & 21,700 \\
\hline
\end{tabular}

a. These figures represent the estimated opportunity costs of Soviet trade to Eastern Europe, or the gap between what the Soviets charge the Eastern Europeans for goods imported from the Soviet Union and the higher prices the Soviets would receive if these goods were exported to the West. While these estimates are subject to debate, given the difficulties involved in establishing exchange rates, spot-market prices for oil, and the like, they seem to be reliable estimates because 1) a great majority of the goods in question are primary products and therefore relatively insulated from problems associated with estimating quality or elasticity of demand; and 2) the arguments supporting the exchange rates used are convincing. For arguments that question whether these estimates may be too high, see Paul Marer, "The Council for Mutual Economic Assistance: Integration or Domination?" in Sarah Terry, ed., Soviet Foreign Policy in Eastern Europe (New Haven: Yale University Press, 1984).

b. The huge jump in 1979-80 reflects 1) the degree to which the Soviets were not able to take advantage of sharp increases in world market prices for energy supplies in intrabloc trade; and 2) the extent of Eastern European energy and trade dependence on the Soviet Union. For example, excluding Romania, 75-93\% of all energy imports in Eastern Europe come from the Soviet Union, and 30-50\% of all trade in these countries is with the Soviet Union. See Morris Bornstein, "Soviet-East European Economic Relations," in Bornstein, Zvi Gitelman, and William Zimmerman, eds., East-West Relations and the Future of Eastern Europe (London: Allen \& Unwin, 1981), pp. 105, 111.

Source. Jan Vanous and Michael Marrese, "Soviet Subsidies to Eastern Economies," Wall Street Journal, 15 January 1982; Vanous and Marrese, Soviet Subsidization of Trade with Eastern Europe (Berkeley: University of California, Institute of International Studies, 1983), pp. $125-30,143-47,198-204,213-26$, and $228-34$.

on Soviet imports. In other words the economic burden of the bloc, so far as trade was concerned, had become much heavier over the course of the Brezhnev era.

These estimates of implicit trade subsidies may be on the high side. ${ }^{28}$ Also, the downturn in world market prices for many primary products and the impact of moving averages based on earlier, higher prices would reduce

28. See Paul Marer, "The Council for Mutual Economic Assistance: Integration or Domination?" in Sarah M. Terry, ed., Soviet Foreign Policy in Eastern Europe (New Haven: Yale University Press, 1984). The central problems addressed by Marer have to do with the degree to which the calculation of subsidies is inflated by assuming seller markets outside the bloc; by postulating too liberal an exchange rate; and by the skewed availability of data on what the Eastern Europeans send to the Soviet Union versus what the Soviets send to Eastern Europe. 
figures since 1980. Nevertheless, there are other ways in which the costs to the Soviet Union of trade within the bloc may be underestimated in the table. First, the table omits the substantial trade subsidies extended to Poland after the crisis of 1980 . In 1981, for example, Poland received raw material and energy supplies from the Soviet Union which were valued at about $\$ 6.7$ billion but which cost the Poles approximately half that amount. Indeed, in that year the Soviets charged the Poles one-half of the OPEC rate for Soviet oil; the charge to the rest of the bloc was 70 to 80 percent of OPEC prices. ${ }^{29}$ Second, these figures on losses from intrabloc trade do not include the costs of reduced Soviet access to Western markets as a result of Eastern European trade dependence, or the costs to the Soviets of the combination of Soviet economic power and Eastern European weakness. With regard to the first point primary products, aside from gold, are the means through which the Soviet Union can gain access to Western trade. And Western trade is critical, since the Soviets rejected a policy of producing valued technological and consumer items during the 1970s in favor of importing such items from the West. Continuing high demand in Eastern Europe for Soviet primary products, therefore, reduces Soviet access to Western markets.

Sizable Soviet exports of necessary items to the bloc mean sizable Soviet imports from the bloc, yet minimal Soviet control over the quality of these imports. If autarchy has meant in practice redundancy, production for domestic consumption, and weaknesses in consumer goods, then high demand for exports means that the Soviet Union functions, in effect, as a captive monopsony receiving redundant and unwanted items. The social surplus, in short, may be easy to transfer within the Soviet bloc, but its form, from the Soviet perspective, has become less and less attractive.

The growth of implicit trade subsidies and other losses from intrabloc trade are not the only economic costs of empire. The Soviet Union also transfers explicit subsidies to her clients-in Mongolia, Vietnam, and Cuba as well as in Eastern Europe (see Table 2). As the estimates in this table indicate, the Soviets have extended substantial hard-currency loansapproximately $\$ 6.2$ billion in 1981 , for example -at what appears to be very low interest and with very flexible, perhaps nonexistent, repayment schedules. At the same time the Soviets appear to have given extensive ruble creditsapproximately $\$ 5$ billion - to Eastern Europe, reflecting in part the growth across the 1970s of Eastern Europe's trade deficits with the Soviet Union. When these estimates are combined with the estimated implicit trade subsidies

29. See Frank Lipsius, "Poland's Cost to the East," New York Times, 7 February 1982; "Now Russia Asks for Time to Pay," Economist, 6 February 1982; John Burns, "Poland an Increasing Economic Burden for Soviets," New York Times, 23 December 1981; Paul Lewis, "As Poland's Economy Slides, Comecon Feels the Backlash," New York Times, 10 January 1982; and Richard Portes, The Polish Crisis: Western Economic Options (London: Royal Institute of International Affairs, 1981). For a recent summary of the Polish crisis, see "Poland's Economy," Economist, 12 February 1983, pp. 71-73. 


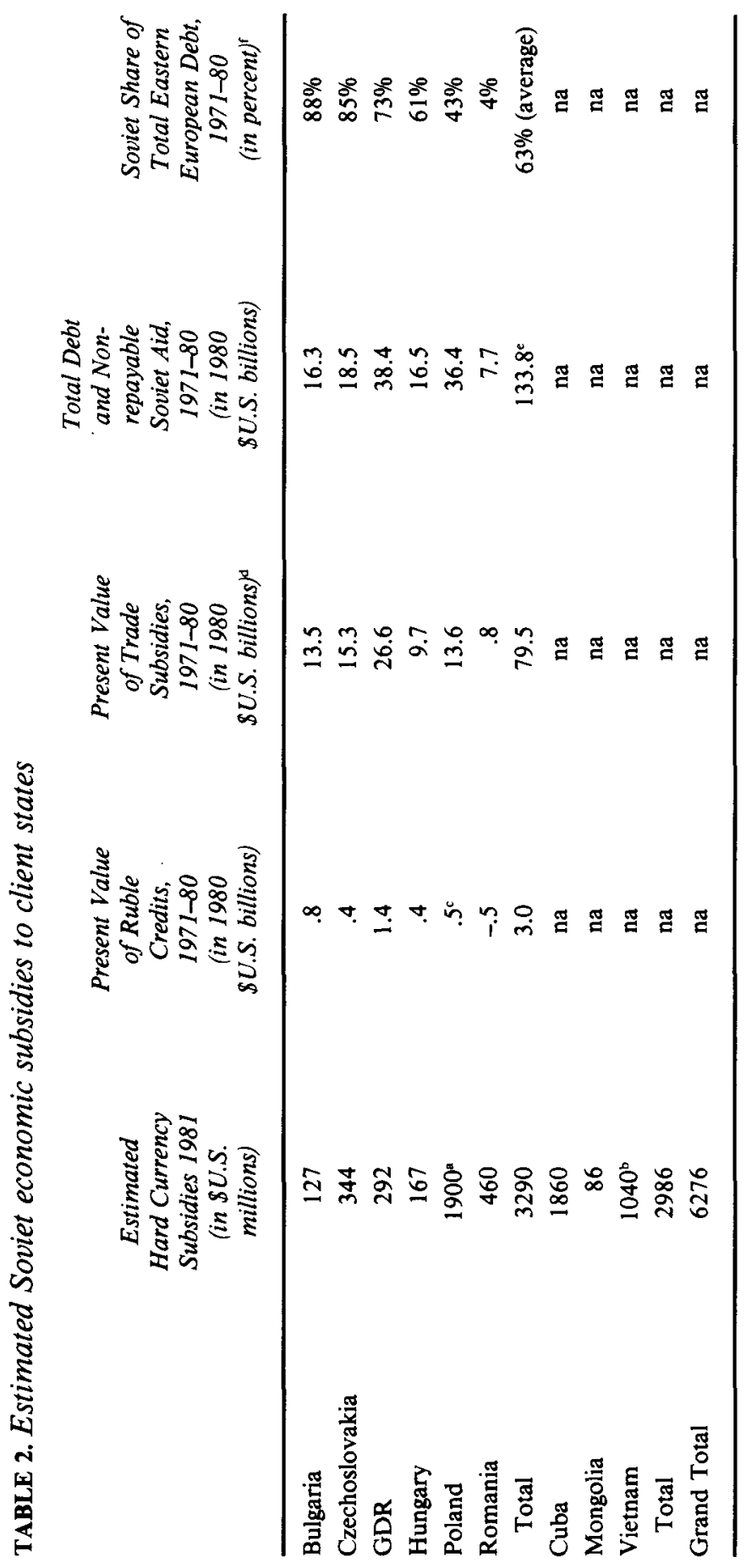




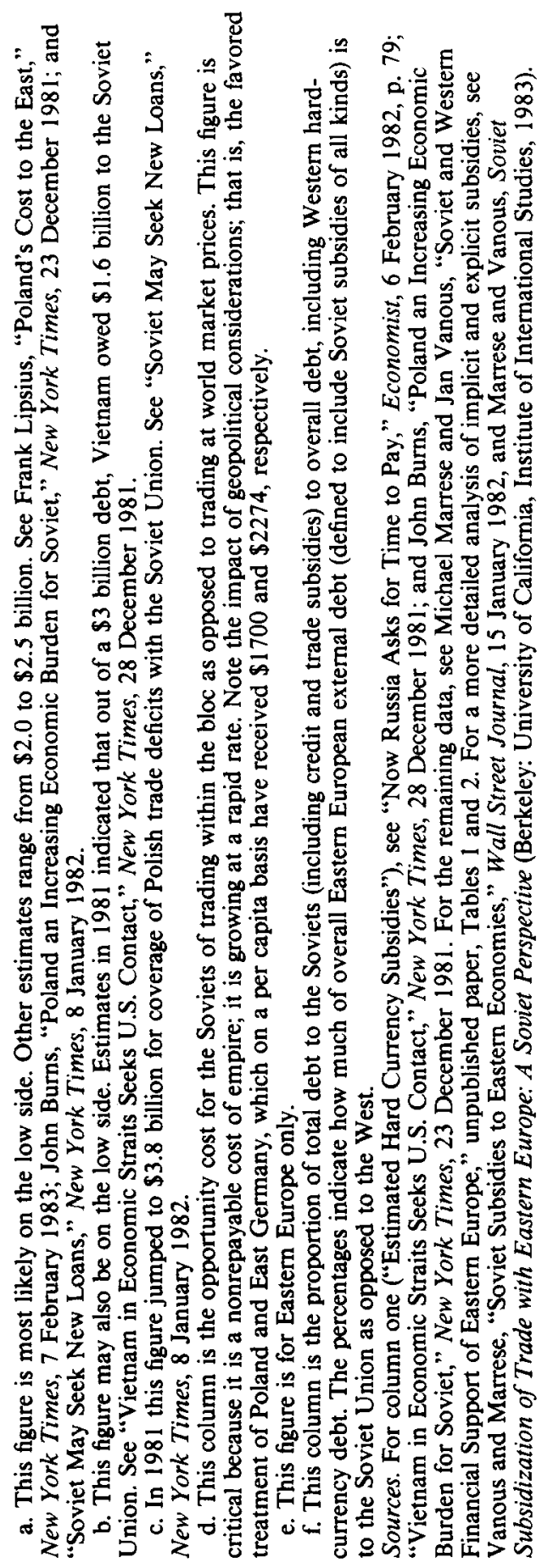


noted above, Soviet aid in all forms to Eastern Europe amounted to (very) approximately $\$ 133.8$ billion between 1971 and 1980 . Indeed, as column 5 in Table 2 indicates, this figure easily outdistanced Eastern European debt to the West.

While a serious drain on the Soviet economy, these explicit subsidies presented in Table 2 do not tell the whole story. For example, ruble credits (and trade subsidies) extended to allies outside Eastern Europe are not included in these two tables, yet they are known to be sizable. While Cuba may be worth $\$ 3$ to $\$ 5$ billion a year to the Soviet Union and Vietnam worth $\$ 2$ billion a year, the fact remains that these colonies are significant economic drains. In addition, Table 2 does not include credits (approximately $\$ 3.8$ billion in 1981 alone) extended to the Poles to cover Soviet-Polish trade imbalances; ${ }^{30}$ such aid has very probably continued. Finally, indirect evidence suggests that the figures for hard-currency loans to Poland in Table 2 are too low. Poland did eventually pay the interest due in 1981 to Western banks and was able to reschedule the principal due in the same year, despite a GNP that declined for a third straight year, falling exports to the West, and a sharp decrease in industrial output between 1980 and 1982. Austerity measures in Poland, moreover, were not as austere as the size of the debt would make one expect.

Did the Soviets provide more to the Poles than Table 2 indicates? Soviet behavior during 1981 indicated a substantial drain on Soviet hard-currency reserves. Examples include the large but difficult-to-explain increase in Soviet debt to the West (from $\$ 17.5$ to $\$ 19.0$ billion); a large increase in Soviet gold sales, despite depressed market conditions; and the failure of the Soviets to use up Western trade credits. Despite depressed economic and unstable political times, the Soviets pressured Eastern Europe to pay more for fewer Soviet goods and to ride out the disruptions in intrabloc trade brought on by the sagging Polish and, indeed, sagging Hungarian, Czechoslovak, and East German economies. ${ }^{31}$ The final evidence concerns the performance of the Soviet economy during this period. Industrial growth, for instance, was supposed to be 4.7 percent in the first half of 1982 but reached only 2.7 percent. Unprecedented in history, moreover, the economic plan for 1982 called for $n o$ increase in the Soviet standard of living. ${ }^{32}$ The burden of the Polish crisis, therefore, would seem to have fallen even more heavily on the Soviet economy than tables 1 and 2 suggest.

30. In 1980, for example, Polish deficits in intrabloc trade reached $\$ 103$ million and, for the first nine months of 1981, reached \$122 million. See Paul Lewis, "Poland's Slump: Endangering Economies of the Soviet Bloc," New York Times, 8 January 1982.

31. See Steven Rattner, "Impact of Soviet Gold Sales," New York Times, 5 January 1982; Ellen L. James, "Is Moscow Reducing Assistance to Cuba?" New York Times, 7 April 1982; "Soviet Fails to Use Gas Pipeline Credit," New York Times, 1 April 1982; "East Germany Tries to Cope," New York Times, 19 July 1982; Vanous, "East European Economic Slowdown."

32. See Prauda, 21 July 1982, and the Yugoslav analysis of Soviet economic problems at the end of the Brezhnev era in "Odlazak velike lichnosti,"NIN (Belgrade), 14 November 1982, pp. $8-11$. 
The nature of Soviet trade in the bloc and the size of Soviet loans and credit to client states together demonstrate that Brezhnev's hopes for a reversal of the trends of the 1960s in intrabloc trade and in Soviet emergency aid did not materialize. The measures taken to limit the economic costs of empire had precisely the opposite effect, as the relationship between Soviet price increases within the bloc, on the one hand, and expansions of implicit and explicit subsidies, on the other, seems to indicate. Originally, the size and resource base of the Soviet economy, Soviet dominance in intrabloc trade, and the Soviet role as a political and economic monopoly had formed the basis of Soviet strength in intrabloc bargaining. Now, all of these characteristics seemed to increase Soviet weakness within the bloc. All economic roads led to Moscow, especially in hard times. ${ }^{33}$

It is hardly surprising that the growth of the Soviet GNP has slowed in recent years, averaging in one estimate only 2.7 percent per year from 1976 to 1980 and actually declining by 1.4 percent in $1980 .{ }^{34}$ The reasons for this slowdown are many, of course, and they include a variety of domestic and international factors. Nevertheless, one reason must be the mounting costs of what may be termed Soviet national security: that is, the costs of "empire maintenance" (or the substantial nonrepayable subsidies noted aboveemergency aid, ruble and hard-currency loans) and the burden of heavy defense outlays (approximately 11 to $12 \%$ of the Soviet GNP or about $90 \%$ of all bloc defense expenditures through the 1970s). ${ }^{35}$

The burden of maintaining control over Eastern Europe has important political costs as well. Imperial conquest is based on the assumption that control over colonies will not only maximize various economic and national security interests but also enhance domestic political stability. The ledger here resists summary with figures, but we can nonetheless make some inferences.

The diversion of scarce economic resources to the client states has contributed to Soviet policies of stringency at home and greater pressure on workers, in particular, as well as on the Party, to produce more with less. ${ }^{36}$

33. In the face of hard-currency problems, two of the more "uppity" states in the regionRomania and Yugoslavia - turned more of their trade toward the Soviet Union. See Statisticki godisnjak Jugoslavije, 1981 (Belgrade: Central Statistical Office, 1981), p. 747, and Jeanne Kirk Laux, "The Limits of Autonomy: Romania in the 1980s," in U.S. Congress, Joint Economic Committee, Eastern European Economic Assessment, Part II (Washington, D.C., 1981), pp. $107-27$.

34. JEC, USSR: Measures of Economic Growth, p. 58.

35. For the figures on defense, see SIPRI, World Armaments, p. 162; JEC, USSR: Measures of Economic Growth; Charles Wolfe, Jr., "Costs of the Soviet Empire," Wall Street Journal, 30 January 1984; Seweryn Bialer, "The Politics of Stringency," Problems of Communism 29 (May-June 1980), pp. 19-33. It must be noted that defense outlays, while they cannot be termed "losses" to the same degree that nonrepayable subsidies can, are nonetheless a very inefficient form of economic investment.

36. See the exhortations directed to the party and the workers to tighten discipline and produce more with less in the November 1982 and the June 1983 Central Committee Plena, which are summarized in "Peredovaya: na vazhneishikh uchastkakh nashei raboty," Kommunist 50 (July 
These policies, needless to say, breed resentment, especially in a time of worker unrest in Eastern Europe and when more Soviet citizens have seen firsthand how good Poles, East Germans, and others have it in comparison with their own position in a consumer-deficit society. ${ }^{37}$ The figures in Table 3 are suggestive (in a rough sense only) of the contrast over time between Soviet and Eastern European economic priorities, and between the quality of life in Warsaw or Prague and Moscow. When this contrast is combined with the belief in many quarters in the Soviet Union that Eastern Europe siphons off Soviet goods, and the mirror-image belief within the client states, the result is a great deal of domestic discontent, in the Soviet Union as well as in the satellites.

This discontent, moreover, will only increase in the future. As the costs of domestic austerity become clear and as the Eastern European regimes, with the plausible exception of Hungary, fall prey to their past habit of failing (and indeed fearing) to prepare a discontented populace for hard times, Eastern European states will undoubtedly turn to the Soviets to lessen the burdens that hard times impose. ${ }^{38}$ The result will undoubtedly be greater pressure on the Party to reform and on the regional hegemon to subsidize reforms. The Polish crisis and unrest in Romania in 1977 in response to economic pressures on workers are, of course, cases in point. ${ }^{39}$ And they are especially telling examples when one considers the unique position of Janos Kádár and the more typical and vulnerable position of other leaders in a bloc prone to spillover effects. If partial socialist encirclement seems to enhance the domestic and foreign security of the hegemonic power, it does so

1983), pp. 3-13, and prefigured in "Luchshe rabotat'-luchshe zhit","Kommunist 49 (April 1982), pp. 3-12. Recent figures on the growth of labor productivity, investment in productive versus unproductive investment, consumption as a percentage of GNP, and economic growth all show the effects of austerity. See A. Bagdasarov and S. Pervushin, "Proizvoditel'nost truda: teorizya, praktika, rezervy rosta," Kommunist 50 (January 1983), pp. 14-23, and JEC, USSR: Measures of Economic Growth.

37. Consider the implications, for example, of the sharp growth in Soviet tourists visiting Eastern Europe, as noted by John Bushnell, "The New Soviet Man Turns Pessimist," in Stephen Cohen et al., eds., The Soviet Union since Stalin (Bloomington: Indiana University Press, 1980), pp. 177-99. Consider as well the implications of higher levels of consumption among party members in consumer-deficit societies, as discussed by Mervyn Matthews, Privilege in the Soviet Union (London: Allen \& Unwin, 1978), and the implications of polls citing resentment over inequalities in privilege cited in David Paul and Maurice Simon, "Poland Today and Czechoslovakia 1968," Problems of Communism 30 (September-October 1981), pp. 25-39.

38. See the arguments by Zvi Gitelman, "The World Economy and Elite Political Strategies in Czechoslovakia, Hungary, and Poland," in Bornstein et al., East-West Relations, pp. 127-61, and Walter Connor, "Workers and Power," in Triska and Gati, Blue Collar Workers. It should be noted that the austerity measures imposed by Eastern European regimes of late are not as austere, insofar as one can gauge such things, as similar measures in nonsocialist Third World countries. The social wage, for example, has not been reduced much and is still substantial. This moderation reflects, among other things, Eastern European fears of austerity-measure "riots" similar to those occurring in Third World countries and seeming Soviet willingness to lessen the domestic costs of the debt crisis in the satellites.

39. See Laux, "Limits of Autonomy," and Arpad Abonyi, "Eastern Europe's Reintegration," in Chase-Dunn, Socialist States in the World System, pp. 181-202. 
only if the proximate periphery is quiescent, growing, deficient in the quality of life by comparison with the hegemon, and supportive of the hegemon's culture. When these conditions were not met, as the Soviets discovered in the Czechoslovak case in 1968, partial socialist encirclement can in fact threaten domestic security and stability. ${ }^{40}$

What began as an ideal empire has evolved in just thirty-five years into an empire that, while still valuable, features fewer assets and many more liabilities. Soviet and Eastern European elites still share interests and the Soviets still hold a monopoly over political and economic resources within the bloc. But if the value of empire is based on the degree to which the colonies help the colonial state achieve its central objectives of economic growth, national security, and domestic political support and political stability, then the value of this empire has declined sharply over a relatively brief span of time.

\section{Why the empire struck back}

Why has Soviet control over Eastern Europe generated fewer and fewer returns? A full explanation must take into account the impact of domestic, regional, and global pressures on intrabloc relations. More specifically, the analysis thus far points to four issues that must be addressed in any full explanation of declining Soviet returns from Eastern Europe. First, why did Eastern European publics demand so much of the state, how were they so cohesive in their actions, and why did they focus their concerns on the issue of immediate improvements in the standard of living? Second, why were these obviously authoritarian states so vulnerable to demands from below and so responsive to them, despite their considerable capacities to behave otherwise? Third, while Soviet emergency aid is easy to explain, other economic transactions within the bloc are not. More specifically, how did all the Eastern European states manage to bargain so consistently well with the Soviets in terms of implicit and explicit subsidies, the defense burden, and domestic investment priorities? In other words, why were the Soviets so accommodating, even during periods of tranquillity within the bloc? Finally, why did the Soviets and the Eastern Europeans decide to terminate regional autarchy and rejoin the global capitalist system? That decision, after all, went deeply against the historical and ideological grain, threatened Soviet monopoly over the region, and eventually undercut the domestic and the foreign interests of both the Soviet Union and the client states.

Some of the answers to these questions can be found in earlier assessments

40. Grey Hodnett and Peter Potichnyj, for example, have argued that a key factor influencing Soviet intervention in Czechoslovakia in 1968 was the feared effects of Slovak irredentism on the Ukrainians. See their The Ukraine and the Czechoslovak Crisis (Canberra: Australian National University, 1972). 


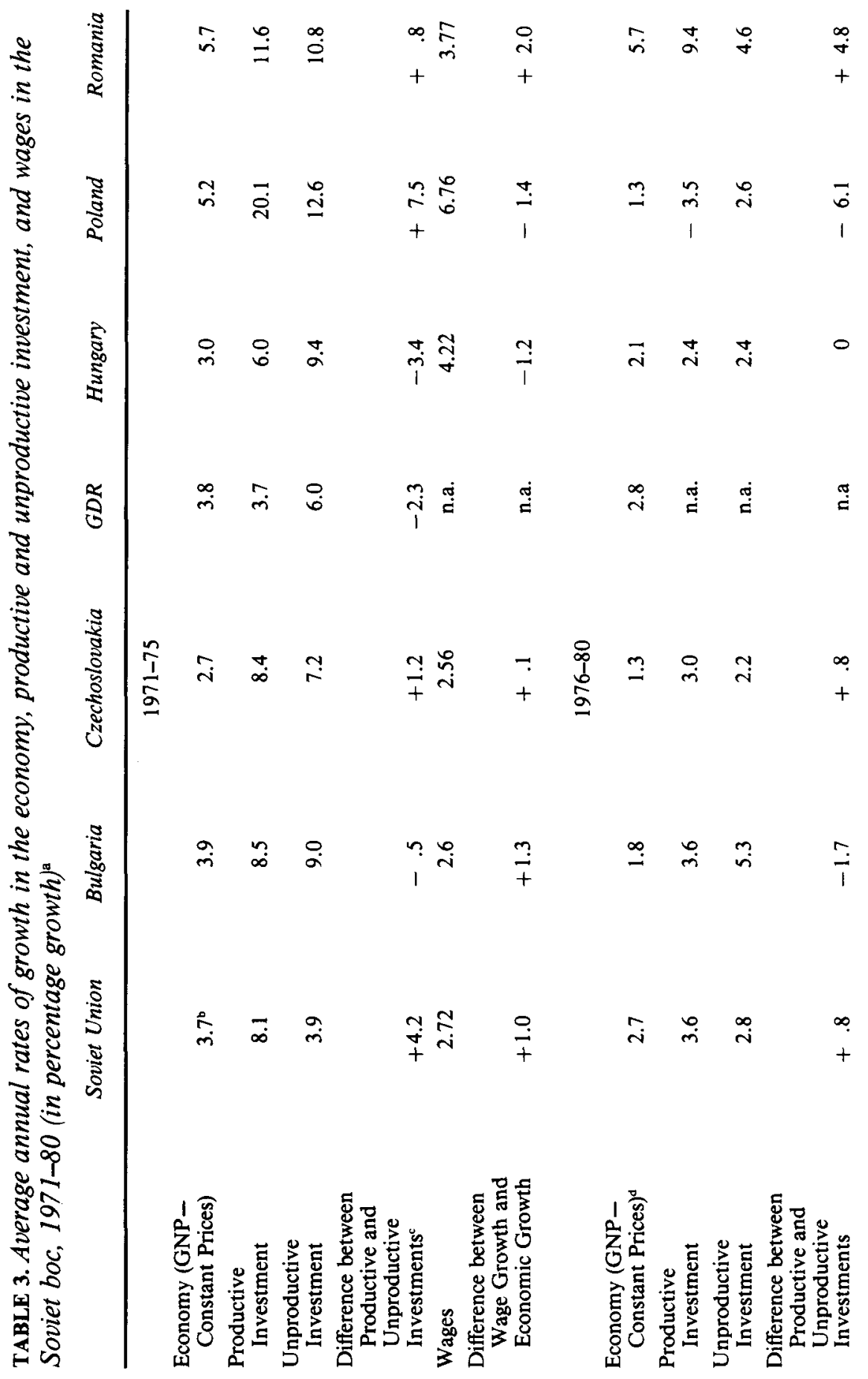




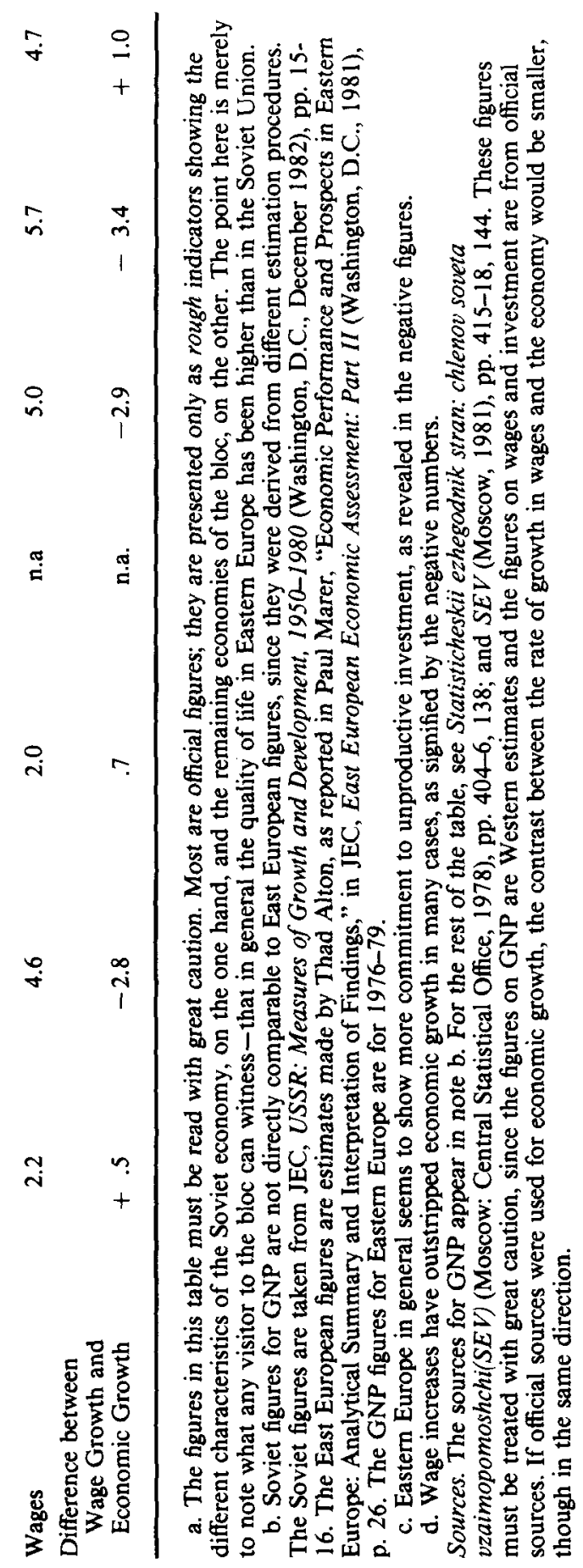


of trade-offs that evolve over time in empires in general and, more specifically, of changes over time in the costs and benefits to member states in this particular empire. Analysts who have focused on relations within the bloc and who treat the nation-state as the unit of analysis emphasize how susceptible bargaining within the system is to free-rider dynamics. Susceptibility increases when bargaining is bilateral, when the system is a regional hierarchical system, and when the smaller states within the regional system manage to gain access to resources outside the bloc. ${ }^{41}$ Other analysts have treated the region as the unit of analysis and focus on the place of the Soviet bloc within the global capitalist system. ${ }^{42}$ They argue that the Soviets had to pay a price for isolating the region from the global capitalist system and had to pay an even higher price for allowing the bloc to evolve into a semiperiphery of the global capitalist system. A final approach, which has been applied in only a limited way to the Soviet bloc, has argued that declining Soviet returns reflected both the natural limits to expropriation of the surplus in empires and the mounting costs associated with imperial control. The growing costs of Eastern Europe can be explained from this perspective as a function of the inherently contradictory objectives of empire and of the long-term costs of expansion. These two factors seem to have led to the development of Janus-faced elites in the colonies. ${ }^{43}$ They also led to the expansion of foreign and domestic competition for political authority and economic goods, and the necessary translation of these pressures into what Robert Gilpin has characterized for empires in general as "The growing conflict among guns, butter or productivity."44

Each of these arguments provides some pieces to a puzzle we might summarize as obvious Soviet power, yet apparent Soviet weakness. Each, however, fails to provide complete answers to the four questions specified above and fails to examine the full range of imperial costs and benefits. The first approach, with its focus on state-level bargaining within the bloc, provides good explanations of why the Soviet Union has been so accommodating to Eastern European demands. It recognizes the susceptibility of the bloc to free-rider

41. For relevant arguments focusing on the distribution of resources available to states for bargaining within the bloc, see Zimmerman, "Regional Hierarchical Systems"; Zimmerman, "Soviet-East European Relations"; Reisinger, "East European Military Expenditures"; Jowitt, "Romanian Communist Party"; Clark, "Evolving Nature"; and Vanous and Marrese, Soviet Subsidization, chap. 8.

42. For similar arguments and suggestive evidence, see Chase-Dunn, "Introduction"; ChaseDunn, "Socialist States"; David Ost, "Socialist World Market as Strategy for Ascent," in Friedman, Ascent and Decline, pp. 229-54; Jowitt, Leninist Response, Gitelman, "World Economy"; Abonyi,

"Eastern Europe's Reintegration"; William Zimmerman, "Dependency Theory and the Soviet-East European Hierarchical Regional System: Initial Tests," Slavic Review 37 (December 1978), pp. 604-23; Clark and Bahry, "Dependent Development."

43. See Theda Skocpol, States and Social Revolutions (New York: Cambridge University Press, 1981).

44. Gilpin, War and Change, p. 167. See also Chirot and Thomas, "World System Theory"; Gilpin, War and Change, pp. 110-16, 146-85; and Triska, "Workers' Assertiveness," especially p. 275. 
effects and the predictably high costs to Soviet security of a failure to respond quickly to Eastern European demands. But, because of its focus on the state, it says little about the origins of demands in the client states or about variations in ability to bargain successfully with the Soviet Union over defense contributions, trade, and aid. Moreover, it makes little sense to treat (as such analyses do) what were in reality severe costs of growing Eastern European dependence on the West and eventually on the East during the 1970s for all concerned as increases in the "resources" available to Eastern European states when bargaining with the Soviets. It is also difficult to explain why the Soviets cut into their own resources and allowed Eastern Europe to gain leverage in intrabloc bargaining by encouraging the termination of regional economic autarchy. In sum, it is difficult to explain the events of the 1970s, or to explain the conflicts between regimes and their societies in Eastern Europe, by relying on arguments that focus on bargaining among states within the bloc. International and domestic forces, in short, are too influential to be treated as givens.

It is precisely these two issues-domestic tensions and global pressureswhich are of central interest to those who examine the Soviet bloc in the context of center-periphery dynamics in the global system. This approach is helpful in explaining why peripheralization of the bloc led to growing tensions within Eastern Europe and led as well to a decline in the resources available to all the states in the bloc. However, this line of argument is less helpful in other regards. First, an analysis that fails to distinguish among bloc states, and at times between the dominant and the small states within the bloc, does not address the variations by state and time in costs over the postwar period. Second, the analysis is not clear about how isolation of the region from the global capitalist system in the 1950s and 1960s translated into growing burdens on the Soviet Union in general, a deterioration throughout the bloc in the terms of trade, and a decline as well in Eastern European contributions to the defense burden. Finally, it is not clear why the Soviets willingly opened the bloc to Western penetration. Such a policy, after all, created essentially "double-dependency" relations, only heightening tensions between Eastern European regimes and their publics and between these states and the Soviet Union.

The third approach, the "decay of empires" thesis, explains why interests shared between Soviet and Eastern European elites in growth and party control generated over the longer term regime-society tensions in the colonies, increased Eastern European pressures on the Soviets to purchase growth and stability in the empire with Soviet rubles, and forced the Soviets to respond to those pressures. But this approach also leaves important questions unanswered. The central issue-why this empire, which was ideally organized to avoid such costs, had such familiar results-cannot be resolved through a focus on imperial decline. Second, why did the Soviet Union ask for trouble 
by "inviting in" foreign competition over resources and authority during the 1970s? Such behavior is, needless to say, contrary to normal imperial policy.

A full explanation of why the Eastern Europeans became so demanding and the Soviets so accommodating demands a combination of these three explanations and hence a sensitivity to the interaction among domestic, regional, and global factors. I first examine the unusual structure of Eastern European states, assessing how the combination of Stalinist political economies at home with political and economic dependence abroad had the effect of poising these states against their publics and focusing public dissatisfaction on the state. I then move from the domestic to the regional level, assessing how the combination of domestic pressures in client states with an asymmetric distribution of political and economic resources among states in a regional hierarchical system had the effect of making the Soviet Union not just a monopoly but, perhaps of greater importance, a political and economic monopsony as well. Control over bloc resources meant that Soviet power within the bloc was not just the "power to persuade" but also, and increasingly, the power to "process" all demands in the bloc and the power to "prevent" their proliferation. Finally, at the global level I argue that the costs to all bloc members generated by growing Eastern European dependence on the Soviet Union led the bloc to increase interaction with the global capitalist system. Indeed, the decision was Pareto-optimal in that all concerned saw it as a means of reducing the burden of Eastern Europe on the Soviet Union while in turn reducing Eastern European burdens at home.

In practice, however, the decision had the opposite effect. Eastern European dependence on the Soviet Union increased domestic pressures on client states. The Soviet Union was forced into the unenviable position of using Soviet resources to prevent economic and political bankruptcy in the bloc. By the 1980s the empire had become more, not less, of a burden for the Soviet Union, and at a time when such burdens could not easily be assumed. Eastern Europe's purported growth in "bargaining power" with the Soviets in fact merely reflected how weak these states had become as a result of their growing economic dependence on Western markets. Soviet losses from empire were not Eastern Europe's gains; growing Eastern European dependence on the Soviet Union could not be construed as Soviet gains. Instead, the resources of all the states in the bloc declined, and that decline was accompanied by a decline in Eastern Europe's value to the Soviet Union.

\section{The consequences of Stalinism for domestic pressures in the periphery}

A Stalinist political economy has the effect, noted earlier, of creating a very strong Party-state, one that fuses and concentrates the political, social, and economic resources of society. In such a system the Party-state functions as 
a political and economic monopoly and monopsony. In the initial years in Eastern Europe such a description said a lot about the power of the parties in Eastern Europe, the power of the Soviet Union, and, as a result, the weakness of society throughout the bloc. In later years, however, it said more about the vulnerability of the Eastern European parties and the Soviet Union to the economic demands of society in the client states.

The combination of Stalinism at home and dependence on the Soviet Union abroad made Eastern European states highly vulnerable to public pressures, and it did so because of five factors. First, states in Eastern Europe were derivative systems, highly dependent on the Soviet Union for primary products and political authority. This dependence reduced the political and economic means that elites in these systems could use to win popular compliance. Nationalist appeals, for example, were difficult to make, and actions opposed to Soviet wishes were difficult to take. At the same time dependence left the Soviet Union with control over all those resources which might be used to prevent or deal with popular unrest in the bloc. The Soviets, therefore, had a monopoly over political, military, and economic resources. They functioned as a captive market for as well as a captive supplier of economic goods and political authority.

Second, a Stalinist system generates very high levels of conflict among elites and among functional interests. Fusion between political and economic arenas, roles, and resources expands and concentrates the stakes associated with losing or winning in the political, economic, or social arena. Fusion also implies an absence of all those safety valves which in more pluralist societies work to diffuse or to rechannel societal conflict. A Stalinist system, as a result, has clear winners and losers. It is unable to blur the distinction between the two through, for example, a focus on the system's ability to deliver money, power, or status; or through an emphasis on the justice of the process of allocation rather than on unjust outcomes; or through tolerance for political, economic, or social nonconformity. High stakes and the absence of alternative arenas in which to mediate conflict and distribute desired goods work to concentrate and heighten political conflicts over the allocation of power, money, and status.

Third, responsibility for allocating all three is concentrated in the hands of the Party. Conflict in such systems, therefore, is not only very focused but focused on the Party. The Party has all the resources, the Party is the arena for interest intermediation, and the Party serves as the expediter in a highly bureaucratic system. Moreover, the Party claims sole responsibility when things go well; it must, therefore, bear responsibility when things go badly. The Party functions as a political monopsony as well as a political monopoly. Such states, in short, must be understood not simply as powerful but also as besieged.

Fourth, just as conflict in Stalinist political economies is intense, "bundled," and concentrated on the Party, so the structure and interests of the Party 
are clear-and clearly antagonistic to the interests of society. The Party wants to maintain control over the economy and the polity, and the Party wants to promote rapid economic growth. Indeed, these goals are interdependent. Political careers in a Stalinist system depend on economic performance, political power is expressed through control over economic resources, and power in the economy carries with it power in the polity and society. Moreover, strong economic performance is unusually important to the functioning of such a system, since a sizable surplus helps regulate and helps dampen the considerable conflict among dominant and always economically based interests built into such systems. Finally, economic success is one of the few available means for legitimating and supporting the prevailing, highly asymmetric distribution of power and economic resources. The maintenance of Party control thus requires low consumption, high investment, and acceptance of these priorities by all those "weak" interests which, if they were strong, would undercut economic growth. Party power, therefore, depends on peasant and worker weakness.

The weakness of society in Stalinist systems, however, is more apparent than real, especially in states that are derivative and externally dependent. The final factor that made many Eastern European states vulnerable to pressures from below was the growing ability of workers to define their interests in opposition to those of the Party and to translate those antagonistic interests into tangible and influential demands. More specifically, workers face a system that prevents popular access to political and social channels, bases its legitimacy in the last analysis on favorable economic comparisons with the presocialist past and on governance for the benefit of workers, and pressures workers with norms. Workers eventually begin to focus on the system's performance as the measure of its legitimacy. At the same time they tend to evaluate that performance from a perspective that is short term, economic in focus, and concerned with outcomes at odds with the shortterm goals of the Party. Workers want reduced pressure at the workplace, more consumption, and expanded opportunities for maneuver in the economy and society-and because of fusion, eventually in the polity as well.

Just as workers in these systems have interests antagonistic to the Party, so they have considerable resources to transform anomic anger into cohesive concerns and cohesive actions. Workers' protest in a workers' state is embarrassing to these regimes. More important, it threatens the underlying dynamics of the system, since no economic grievance in a Stalinist political economy is without political or social impact. And the very structure of these systems tends to encourage the development of working-class cohesion. One can point, for example, to the great postwar expansion of the working class in these rapidly developing societies; their concentration into large factories; and the similarities in worker experiences, similarities that result from regime policies and policy shifts which, because of fusion and centralization, affect all workers in the same way at the same time. Blame for bad conditions can 
easily be assigned to the Party, and strength comes from guaranteed employment, labor shortages in many cases, and the sizable social wage that exists in state-socialist systems. Workers have additional power, albeit potential, as a result of growing deficiencies in capital and the precedent of periodic worker unrest in the bloc. Finally, the Party's ability to win workingclass compliance grows more limited as opportunities for social mobility and income redistribution narrow with lower growth and completion of the initial industrial breakthrough.

We can add to this list the short-term horizons of workers, a result of their emphasis on policy outcomes rather than public inputs into the policy process, the failure of such systems to provide the public with information on political or economic issues, and the inherent difficulties elites in statesocialist systems have in blaming workers for lower growth. All in all, it is easy to see why workers often become demanding and why elites in such systems are vulnerable to worker demands. It is also easy to see why the Party in Eastern Europe responds to popular unrest in the way it does. It is a Pareto-optimal solution to buy working-class compliance in the short term through expanded consumption and thereby protect the privileged position of the Party by maintaining the basis of Party power: centralization and fusion of the polity and the economy.

The responsiveness of Eastern European elites to economic demands from below has forced elites in the periphery to mortgage economic growth over time by responding to short-term economic demands and short-term political needs. These issues were introduced by de-Stalinization in the 1950s, and the ways in which these issues were then resolved in Eastern Europe have become standard operating procedures (see Table 3). Indeed, given the considerable and mounting costs to both Soviet and Eastern European elites of extrication from this political consumption cycle, concern with public consumption in the satellites became a necessary procedure. A social compact evolved in Eastern Europe as a result. These states exchanged tangible economic benefits, greater equalization in the distribution of income, low norms for worker productivity, and some loosening of cultural barriers and social norms for the continuation of Party dominance over the polity and economy, worker compliance with social, economic, and political norms, and public tolerance for Soviet influence and protection abroad. ${ }^{45}$

A compromise was forged at the intersection between public and Party interests, constraints, and bargaining capacities. That compromise translated domestic pressures in the periphery into an ongoing economic courtship of

45. See in particular Zvi Gitelman, "Power and Authority in Eastern Europe," in Johnson, ed., Change in Communist Systems, pp. 235-64; Zygmunt Baumann, "Twenty Years after: The Crisis in Soviet Type Systems," Problems of Communism 20 (November-December 1971), pp. 45-53, Gitelman, "World Economy"; Alex Pravda, "East-West Interdependence and the Social Compact in Eastern Europe," in Bornstein et al., East-West Relations; Triska, "Workers' Assertiveness"; Bahro, Alternative, p. 207; and Konrad and Szelenyi, Intellectuals on the Road. 
the population. ${ }^{46}$ It was particularly noticeable in those countries which had a history of worker unrest, a sizable working class, access to the West, and limited domestic support for the revolution and the Party-Hungary, Poland, Czechoslovakia, and the GDR. The most extreme case, as recent events and the data in tables 1 to 3 indicate, has been Poland. Here, ethnic and religious homogeneity, the precedents set by regime receptiveness (and Soviet acquiescence) to mass discontent in 1956, 1970, 1975-76, and 1980, historical tensions between Poland and Russia, a Party that continually postponed its economic and political day of reckoning for short-term political reasons, and an economy that in the 1970s provided a textbook case of unrest as a function of rising expectations - all led, when combined with factors noted above, to the first historical case of a genuine, albeit stillborn, proletarian revolution. ${ }^{47}$

The uneasy truce between Party and society in Eastern Europe maximized the short-term interests of both: it kept the Party in control and society in some economic comfort. But the truce worked against two long-term interests that these parties and their publics necessarily shared: reduction of economic and political dependence on the Soviet Union, and maintenance of a rapidly growing economic surplus that would help contain intraelite and Party-society conflict over the distribution of vital resources. By the late 1960s it was clear that Eastern Europe depended more and more on the Soviet economy. It was also clear that the rate of growth in these economies (in particular in Poland, Hungary, and Czechoslovakia) was not equal to meeting the social contract, continuing high levels of economic investment (particularly vital, given declining returns on capital), satisfying defense obligations, and meeting the concerns of all those interests which were accustomed to privilege. Something had to give. That something was the Soviet Union.

\section{The costs of power and weakness: the impact of a regional hierarchical system}

The dependence of Eastern European regimes on economic growth and rising consumption at home and on the Soviet economy, the Soviet military, and Soviet party patronage abroad proved to be a source of some strength, not weakness, in bargaining with the Soviet Union. The Soviet Union was at the same time the largest market, the dominant trade partner, and the central

46. Bogdan Mieczkowski, "The Relationship between Changes in Consumption and Politics in Poland," Soviet Studies 30 (1978), pp. 263-69; Triska and Gati, Blue Collar Workers; and Longin Pastusiak, "Origins and Nature of the Polish Crisis, 1980-1981," unpublished paper (Ohio State University, Mershon Center, 9 February 1984).

47. The limits of worker power are analyzed by Connor, "Workers and Power"; Adam Przeworski, "The 'Man of Iron' and Men of Power in Poland," PS 15 (Winter 1982), pp. 18-31; and David Mason, "Policy Dilemmas and Political Unrest in Poland," Journal of Politics 45 (1983), pp. 397-421. Mason's analysis suggests that, in the Polish case at least, worker power is central and worker pressure on the regime's priorities is evident even prior to succession. 
supplier of primary products in the bloc. As regional hegemon, moreover, the Soviets supplied crucial political resources to their derivative client states, dominated all political transactions within the bloc, and defined the boundaries of the system. Soviet "strength" was considerable. This strength opened the Soviets up to the free-rider problem. Moreover, the derivative and dependent nature of these states and Soviet concerns with domestic security made the Soviets highly vulnerable to fears of unrest in the colonies and highly responsive to the argument that domestic Party control in Eastern Europethe linchpin of Soviet control over the bloc-had to be maintained at all costs. Finally, economic subsidies were far less costly than political and economic reforms. The latter course of action would have jeopardized the necessary linkage in the bloc between sizable domestic and sizable international inequalities in power and control over economic resources.

The empire, therefore, was worth a lot to the Soviet Union, and it was (in practice or by way of contagion) vulnerable to domestic unrest. At the same time only the Soviets had the capacity to do something about such effects, and only opting for substantial economic subsidies would keep the system intact and strengthen the bonds between powerful elites in the center and the "reflective" power of the elites in the periphery.

As noted above, the Soviets initially saw the logic of subsidies as a small price to pay for bloc stability. By the late 1960 s, however, it was clear that subsidies were not a viable long-term solution. The Soviet Union, with its declining domestic reserves, could do only so much. Moreover, capital was scarce throughout the bloc; and because of labor shortages and structural limits to worker output, higher productivity depended more and more on technology unavailable inside the bloc. Finally, a policy of enhancing the purchasing power of the public in Eastern Europe could not quell discontent if there was little for the public to purchase with the money and if the goods they wanted were not easily produced and distributed by centrally planned economies.

Together, these problems of Soviet "strength" and Eastern European "weakness" eventually pointed the bloc toward Western trade. In the context of global recession, they also pointed it toward an accumulation of large Western debts and a deterioration in the Eastern European terms of trade. ${ }^{48}$ With the termination of regional autarchy, dependency relations within the bloc merely deepened in consequence of the semiperipheralization of the bloc within the global capitalist system. And, in turn, all the contradictions

48. It was hoped, according to the arguments supporting the new stage of "Developed Socialism," that greater equalization in income distribution by class during the 1960 s would enhance productivity. See Bunce, "Political Economy"; Walter Connor, Socialism, Work, and Equality (New York: Columbia University Press, 1979); and Bogdan Mieczkowski, Personal and Social Consumption in Eastern Europe (New York: Praeger, 1977), pp. 149, 196-98, 225, 273, and 311. As Jozef Pajestka put it (quoted in Mieczkowski, p. 189), "a better satisfaction of human needs favors faster economic growth." 
noted above deepened as well, enhancing the already sizable burdens generated by the social contract and the pressures that the contract exerted on the bloc.

\section{Joining the periphery of the global capitalist system}

The termination of regional economic autarchy involved two related policy shifts: a lessening of political tensions between East and West, or "razriadka," and Soviet encouragement of economic transactions between the bloc and developed capitalist systems. From the perspective of both Soviet and Eastern European elites, such dramatic shifts in policy seemed at the time to resolve pressing problems at home and abroad. For the Soviets, in particular, the successful pursuit of "razriadka" held open the possibility of expanding domestic economic flexibility by easing the pressure of high military outlays over time. The defense burden was especially great in the Soviet case because of lower growth, because the Soviet economy was a little more than onehalf the size of its American competitor, and because the Soviets were also defending against the Chinese threat. Some easing of the fiscal burden on the state carried other appealing outcomes, among them the release of all the human as well as the material capital that a capital-intensive defense sector had been absorbing. In addition, détente promised as much, if not more, flexibility in Soviet dealings with the rest of the world as autarchy had delivered. There would be greater predictability in Western actions if EastWest relations and spheres of influence were clearly defined. One source of tension in Soviet bloc relations - the growing pressures on Eastern Europe to shoulder more of the defense burden - would be removed. Finally, and perhaps more realistically, East-West political cooperation could act as a wedge to expand economic and scientific exchanges with the West. In this sense, Brezhnev, Nixon, and Kissinger saw eye to eye on the benefits of détente. ${ }^{49}$

"Razriadka" went hand in hand with the decision to terminate regional economic autarchy. Trade with the West offered the Soviets and the Eastern Europeans a way out of the dilemmas posed by too little growth and too many claimants on the surplus, by growing pressures for political and economic reforms that would necessarily undercut "Planner" and Party sovereignty, and by the necessity of moving toward capital-intensive growth and the provision of more consumer goods. Trade with the West and Western credits were ways of getting out of bottlenecks, political as well as economic.

49. For Soviet views of "razriadka," see G. L. Rozanov, Politika sotrudnichyestva-veleniye vremeni SSSR i kapitalisticheskiye strany, 70-ye gody (Moscow: Mezhdunarodnye otnosheniya, 1977); E. S. Shersnev, SSSR-SShA: ekonomicheskiye otnosheniya i problemyi vozmozhnosti (Moscow: Nauka, 1976). Compare how similar these arguments are with those of Richard Nixon, RN: The Memoirs of Richard Nixon (New York: Warner, 1978), pp. 89-105. 
Certain external benefits were foreseen from greater economic contact with the West as well. Eastern European political and economic dependence on the Soviet Union might lessen. Domestic pressures were to be ameliorated by growth and an infusion of Western goods. The smaller countries could maximize their advantages by plugging into the international division of labor (which was critical, given the parallel deficiencies dictated by derivative economic systems). Moreover, the proportion of trade with the West could reduce the enormous economic pressures on the Soviet Union within CMEA, the regional trade organization..$^{50}$ Some Soviet and Eastern European economists also felt that producing for the world market rather than for captive consumers would force an improvement in the quality of goods produced within the bloc. All the benefits of Western market mechanisms could be imported, then, while avoiding all the problems that a wholesale adoption of such mechanisms at home would generate-for example, widening income differentials by class as external prices took over, increasing unemployment, and reduction in the economic and political control exercised by the Party. ${ }^{51}$

On the Western side similarly positive calculations were made. Détente, before misconstrued as a result of short-term political pressures, particularly in the United States, was seen as advantageous to Western interests. ${ }^{52}$ It offered savings and reduction in global tensions and promised greater flexibility in foreign policy. It also held out the attractive prospect of access to a huge, untapped market capable of absorbing both the dregs and the growth exports of the Western economies-for example, lower-quality consumer goods, German steel, American grain, manufactured goods in general, and high (and not-so-high) technology. Access in the process to the Soviet bloc's raw materials and energy supplies was only enhanced by the congruence of these markets with bankers' ideals: the presence of captive consumers, steady demands, strong governments, and the Soviet fiscal and political umbrella. Western bankers thought "centrally planned economies [in contrast to the Third World] could always be kept solvent." ${ }^{33}$ Indeed, as David Rockefeller has summarized, "in terms of straight credit risk, the presumption is that

50. See, in particular, Kalman Pesci, The Future of Socialist Economic Integration (Armonk, N.Y.: Sharpe, 1981); Fredrich Levcik and Jan Stankovsky, Industrial Cooperation between East and West (White Plains, N.Y.: Sharpe, 1979), pp. 41-54; Bornstein, "East-West Economic Relations"; and Franklyn D. Holzman and Robert Levgold, "The Economics and Politics of East-West Relations," in Erik Hoffman and Frederic Fleron, eds., The Conduct of Soviet Foreign Policy, 2d ed. (New York: Aldine, 1980), pp. 428-78.

51. Pesci, Future, p. 162; Friedrich Levcik, "The Prospects for East-West Trade in the 1980s," in Bornstein et al., East-West Relations, pp. 62-86.

52. On the U.S. misconstrual see in particular Lawrence Radway, "The Curse of Free Elections," Foreign Policy no. 40 (Fall 1980), pp. 61-73; Coral Bell, "Soviet American Strategic Balance, the Western Alliance, and East-West Relations," in Bornstein et al., East-West Relations, pp. $11-30$.

53. Paul Marer, quoted in Paul Lewis, "Role of Western Banks in Poland's Debt Crisis," New York Times, 3 February 1982. For a Soviet view of these issues, see L. Bauman and B. Grebnikov, "The Socialist Community: Economic Integration," International Affairs (Moscow) 22 (1981), pp. 73-81. 
TABLE 4. Soviet bloc trade with the West

\begin{tabular}{lccccccc} 
& 1971 & 1973 & 1977 & 1978 & 1979 & 1980 & 1981 * \\
\hline $\begin{array}{l}\text { Exports } \\
\quad \text { (\$U.S. billions) }\end{array}$ & 6.7 & 12.9 & 27.5 & 32.5 & 41.1 & 47.1 & 51.4 \\
$\begin{array}{l}\text { Imports } \\
\quad \text { (\$U.S. billions) }\end{array}$ & 7.6 & 16.4 & 33.8 & 38.3 & 45.1 & 51.6 & 56.9 \\
Trade Deficits & -1.1 & -3.5 & -6.3 & -5.8 & -4.0 & -4.5 & -5.5 \\
Current Account & n.a. & n.a. & -8.5 & -5.5 & -3.2 & -4.6 & -6.2 \\
\hline
\end{tabular}

a. Recent trends indicate an improvement in the current account, with Eastern European imports from the West down 16\% in 1982. See "Curtain Call," Economist, 3 December 1983 , p. 92.

Sources. Roger Kanet, "East-West Trade and the Limits of Western Influence," in Charles Gati, ed., The International Politics of Eastern Europe (New York: Praeger, 1976), p. 205; World Economic Outlook (Washington, D.C.: IMF, June 1981), p. 154. The figures for 1981 are estimated. Broken down, the data indicate that 1) growth in trade with the West was particularly large for Poland, Hungary, the Soviet Union, and East Germany, and declining for Bulgaria and Romania; 2) the Soviet Union remained easily the dominant trade partner for the Eastern European states (with the exception of Romania); 3) the primary decline in trade over time was inter-Eastern European trade; and 4) trade deficits were produced by Eastern Europe, not for the most part by the Soviet Union.

there is greater continuity of government in certain socialist states than in non-socialist systems." 54

As Western politicians sought a strong economy, Western bankers sought reliable clients and, after 1974, outlets for petrodollars. For both groups, the opening up of the Soviet bloc was a very positive prospect. Convergent interests between East and West led to a rapid expansion of East-West trade over the course of the 1970 s - a ninefold increase from 1970 to 1981 of Western exports to the bloc, and an eightfold increase in the same period of Western imports from the Soviet bloc (see Table 4).

The impact of this expansion on the East and the West, however, was asymmetrical. Western involvement was somewhat greater than is implied by the small percentage of Soviet bloc trade in overall Western trade (rarely reaching $5 \%$ of overall trade, except in West Germany and Austria). ${ }^{55}$ Never-

54. Quoted in Anthony Sampson, "So, Give Credit Where Credit Is Due (Poland)," New York Times, 10 January 1982. See also Gabriel Eichler, "Country Risk Analysis and Bank Lending to Eastern Europe," in JEC, Eastern European Economic Assessment, 2:759-75; "The Country Risk League Table," Euromoney, February 1982, p. 46; and Franklyn Holzman, "Credit Worthiness and Balance-of-Payments Adjustment Mechanisms of Centrally Planned Economies," in Steven Rosefielde, ed., Economic Welfare and the Economics of Soviet Socialism (Cambridge: Cambridge University Press, 1981), pp. 163-84.

55. For example, it has been estimated that such trade furnishes $1 \%$ of the West German GNP, provides 92,000 jobs to West Germany (particularly in steel), and, with the pipeline deal, will provide some 20,000 more jobs to the seven European nations involved. Finally, there is energy dependence. In the early 1980 s, $17 \%$ of West German domestic gas consumption is 
TABLE 5. Trade as percentage of gross material product ${ }^{\mathrm{a}}$

\begin{tabular}{lccc} 
& \multicolumn{3}{c}{$\begin{array}{c}\text { Overall Trade as Percentage } \\
\text { of Gross Material Product }\end{array}$} \\
\cline { 2 - 4 } & $1966-70$ & $1971-75$ & $1976-79$ \\
\hline Bulgaria & 20.0 & 25.0 & 26.0 \\
Czechoslovakia & 15.0 & 16.0 & 17.5 \\
GDR & 16.0 & 19.0 & 20.3 \\
Hungary & 20.0 & 23.0 & 24.8 \\
Poland & 10.0 & 12.0 & 13.7 \\
Romania & 11.0 & 13.0 & 14.8 \\
Soviet Union & 3.9 & 4.7 & 5.1 \\
\hline
\end{tabular}

a. When broken down by region, the data indicate that Eastern European trade in general focused on the West and the Soviet Union, and that Poland, Hungary, and the Soviet Union show the largest increases in trade with the West over the mid-to-late 1970s. See Arpad Abonyi, "International Development of Labor and Industrial Readjustment in Hungary: Dependent Industrialization and the Limits of State Strategy-The Consequences for the Automobile and Machine Tools Industries," paper delivered at the International Studies Association convention in Cincinnati, Ohio, 24-29 March 1982.

b. These percentages would be higher if Gross National Product were used as the denominator instead of GMP. In the Soviet case, for example, one estimate places trade as a percentage of the official GNP at $7.7 \%$ in 1980 . See JEC, USSR: Measures of Economic Growth and Development, 1950-1980 (Washington, D.C., December 1982), p. 17.

Sources. Eleftherios Botsas, "Pattern of Trade," in Stephen Fisher-Galati, ed., Eastern Europe in the 1980s (Boulder: Westview, 1981), pp. 80, 94; United Nations, Economic Bulletin for Europe vol. 33 (New York, 1981), p. 1.8.

theless, the fact remains that Ostwirtschaft's impact was more dramatic in the East than in the West. In the Soviet bloc the expansion of trade with the West moved Eastern Europe toward somewhat greater trade dependence in general (see Table 5). Trade expansion led to a deterioration for Eastern Europe in the terms of trade with the West and also with the Soviet Union, because the Soviets increased the price they charged for primary products and because the market for Eastern European manufactured goods was weak. It also led to mounting trade deficits with the West (registered in Table 4), and rising surpluses in Soviet trade with Eastern Europe. ${ }^{56}$

Of greater importance to the East, and increasingly to the West as well, was mounting Soviet Bloc debt to Western banks and Western governments, especially in the wake of the energy crisis of 1973-74, the global recession in 1979-81, and the surfeit of petrodollars in Western banks (see Table 6).

provided by the Soviets, a figure expected to rise to $30 \%$ by the 1990 s and to $20 \%$ for other Western European countries. See Angela Stent, "The USSR and Germany," Problems of Communism 30 (September-October 1981), pp. 1-23; John Tagliabuc, "Bonn Needs the Business Even More Than the Gas," New York Times, 14 August 1981.

56. See Joan Parpart Zoeter, "Eastern Europe: The Hard Currency Debt," in JEC, Eastern Europe Economic Assessment, vol. 1 (1981), pp. 716-31. 
As the figures indicate, gross debt to the West (only an average of $63 \%$ of Eastern European total debt, broadly conceived, to the Soviet Union) grew rapidly, from $\$ 6.5$ billion in 1970 to approximately $\$ 88.1$ billion by 1981 . The seriousness of this economic burden for Eastern Europe is revealed in the dramatic increases in the debt-service ratio since 1977 and the ratio of total debt to annual hard-currency export earnings (see Table 7). ${ }^{57}$ Indeed, by 1981 the ratio of total medium and long-term hard-currency debt to hard-currency export earnings for the bloc as a whole was reaching 170, a figure that goes even higher when Eastern European hard-currency debt to the Soviet Union, $\$ 3.3$ billion for 1981 , is added.

By the late 1970s, then, the global recession and the substantial difficulties that autarchic economies of the state-socialist type face in expanding hardcurrency trade had together turned what seemed to be a rational decision into one carrying grave economic consequences. Indeed, Eastern Europe had taken on many of the characteristics of a semiperiphery within the global capitalist system. There was growing indebtedness to the capitalist core, growing trade dependence in general and on the West in particular, a deterioration in the terms of trade, and negative trade balances (see Tables 4 , 5 , and 8).$^{58}$ There were also the familiar externalities associated with high levels of debt in small, rather specialized economies unable to adjust to changing market conditions. Examples were many: structural difficulties arising from planning and the bloc division of labor in expanding the range of export items and pursuing import-substitution policies; the importation of Western business cycles with their clear effects in 1973-74 and 1979-81 on deficits, debts, and development; some indications of growing income inequalities; ${ }^{59}$ reduced fiscal flexibility of the state; "creeping" market-oriented reforms; in some cases growing imports of food; ${ }^{60}$ and the imposition, first

57. By 1976-77, for example, Poland was borrowing for current consumption needs. See Karin Lissakers, "The Polish Debt," New York Times, 8 January 1982. For a discussion of the mechanics of the "debt regime," see Charles Lipson, "The International Organization of Third World Debt," International Organization 34 (Autumn 1981), pp. 603-31; Ortmeyer, "Poland's Foreign Debt"; Portes, "The Polish Crisis"; Zoeter, "Eastern Europe"; and Lawrence Brainard, "Eastern Europe's Uncertain Future: The Outlook for East-West Trade and Finance," in JEC, Eastern European Economic Assessment, 1:751-58.

58. In 1979 Eastern Europe's current-account balance was negative $\$ 5$ billion. In 1980 the figure was -4.8 , and in $1981-5.5$. The Soviet Union, by contrast, ran considerable trade surpluses in the bloc and in the world. See United Nations, Economic Bulletin for Europe vol. 33 (New York, 1981), p. 116.

59. The linkage between external dependence and patterns of income inequality in Eastern Europe is examined in Bunce, "Neither Equality Nor Efficiency." For interesting insights into this linkage from an Eastern European perspective, see Zsuzsa Ferge, $A$ Society in the Making: Hungarian Social and Societal Policy, 1945-1975 (White Plans, N.Y.: Sharpe, 1979), pp. 159-91.

60 . For example, while Poland traditionally has been a net food exporter, by the late $1970 \mathrm{~s}$ Poland was a net food importer. This change reflected sharp declines in livestock beginning in 1977 and sharp declines in crop production beginning in 1978. See Paul Lewis, "Economic Revival Called Polish Aim," New York Times, 15 December 1981. Hungary, by contrast, has become a net food exporter, in part because the Hungarians have instituted significant organizational reforms in the countryside and have capitalized on Western technology and cooperative 
TABLE 6. Estimated Eastern bloc medium- and long-term hard currency gross debt to the West (\$U.S. billions)

\begin{tabular}{|c|c|c|c|c|c|c|c|c|c|c|}
\hline & 1970 & 1974 & 1975 & 1976 & 1977 & 1978 & 1979 & 1980 & $1981^{\circ}$ & $\begin{array}{c}\text { Debt Incurred } \\
\text { by Eastern } \\
\text { Europe to the } \\
\text { West and the } \\
\text { Soviet Union } \\
1971-80\end{array}$ \\
\hline Bulgaria & 0.7 & 1.2 & 1.8 & 2.3 & 2.7 & 4.3 & 4.5 & 4.5 & 4.8 & 16.3 \\
\hline Czechoslovakia & 0.3 & 1.1 & 1.5 & 2.1 & 2.7 & 3.2 & 4.0 & 4.5 & 4.8 & 18.5 \\
\hline GDR & 1.0 & 2.8 & 3.8 & 6.0 & 5.9 & 8.9 & 10.1 & 11.5 & 12.5 & 38.4 \\
\hline Hungary & 0.6 & 1.5 & 2.1 & 2.8 & 3.4 & 7.5 & 7.8 & 8.9 & 8.0 & 16.5 \\
\hline Poland & 0.8 & 3.9 & 6.9 & 10.2 & 13.0 & 17.8 & 20.5 & 23.0 & 27.0 & 36.4 \\
\hline Romania & 1.2 & 2.6 & 3.0 & 3.3 & 4.0 & 5.2 & 6.9 & 9.5 & 12.0 & 7.7 \\
\hline Total & 4.6 & 13.1 & 19.1 & 25.7 & 31.7 & 46.9 & 53.8 & 61.9 & 69.1 & 133.8 \\
\hline Soviet Union & 1.9 & 5.0 & 10.0 & 14.0 & 16.0 & 16.5 & 17.2 & 17.5 & 19.0 & n.a. \\
\hline Total for Bloc ${ }^{b}$ & 6.5 & 18.1 & 29.1 & 39.7 & 47.7 & 63.4 & 71.0 & 79.4 & 88.1 & n.a. \\
\hline
\end{tabular}

a. Estimates indicate that bloc debt to the West fell to about $\$ 80$ billion in 1982 and fell still further to approximately $\$ 62$ billion in 1983. See "Curtain Call," Economist, 3 December 1983, p. 192, and Seth Mydens, "East Bloc Lending Climate Improves," New York Times, 5 March 1984, p. 23.

b. Does not include debts incurred by CMEA banks, which range from $\$ 0.1$ to $\$ 2.8$ billion, 1970-81.

Sources. Morris Bornstein, "Issues in East-West Economic Relations," in Bornstein, Zvi Gitelman, and William Zimmerman, eds., East-West Relations and the Future of Eastern Europe (London: Allen \& Unwin, 1981), p. 37; Marrese and Vanous (see Table 2); Allen Lenz and Robert Teal, "Projected CMEA Hard Currency Debt Levels under Selected Growth Assumptions," p. 745, and Paul Marer, "Economic Performance and Prospects in Eastern Europe: Analytical Summary and Interpretation of Findings," p. 57, both in JEC, The Eastern European Economies, vol. 2 (Washington, D.C., 1981).

agreements to maximize output. See Sheila Theff, "Hungary Harvesting the Fruit of U.S. Farming Know-How," Chicago Tribune, 24 June 1982; Paul Lewis, "What Poland Lacks, Hungary Has Aplenty," New York Times, 16 December 1981. Indeed, by 1979 only Czechoslovakia, Hungary, and Romania were net agricultural exporters. 
TABLE 7. The burden of debt in the Soviet bloc and some comparisons (percentages)

\author{
Total Western Debt \\ by End Year 1980 as \\ Percentage of Hard- \\ Currency Export \\ Earnings
}

Western
Debt-Service
Ratios $^{a}$

$1970 \quad 1977 \quad 1980$

\begin{tabular}{lcccc}
\hline Bulgaria & $347 \%$ & $35 \%$ & $85 \%$ & $35 \%$ \\
Czechoslovakia & 143 & 8 & 34 & 22 \\
GDR & 290 & 20 & 40 & 40 \\
Hungary & 307 & 20 & 44 & 45 \\
Poland & 390 & 20 & 60 & 105 \\
Romania & 264 & 36 & 42 & 28 \\
Soviet Union & 71 & 18 & 28 & -6 \\
$\quad$ & & & & 47 \\
$\quad$ Average & 145 & 22 & & 40 \\
All Non-Oil & & 25.8 & 23.7 & 26.6 \\
$\quad$ Developing Nations & $52^{\mathrm{a}}$ & n.a & n.a. & 58 \\
Brazil & $33^{\mathrm{a}}$ & n.a. & n.a. & 45 \\
Mexico & & & & \\
\hline
\end{tabular}

a. The ratio of payments (interest and principal due) to exports of goods and services earnings in Western interactions only.

b. On long-term debt only, so not directly comparable to the overall debt.

Sources. IMF, World Economic Outlook, June 1981, pp. 135-37; Marrese and Vanous (see

Table 2); "Sanctions after Poland," Economist, 30 January 1982, p. 30.

\section{in Bulgaria and then in Romania, Poland, Hungary, and the GDR, of domestic austerity measures. ${ }^{61}$}

61. See "Curtain Call," Economist, 3 December 1983, p. 92; Binder, "Czechs Are New Economic Casualties"; Egon Neuberger, Richard Portes, and Laura D'Andrea Tyson, "The Impact of International Economic Disturbances on the Soviet Union and Eastern Europe: A Survey," in JEC, Eastern Europe, vol. 2 (1981), pp. 128-47; articles by Doris Cornelson, Ed Hewett, and Friedrich Levcik, in JEC, Eastern Europe, vol. 1 (1981); Paul Hare, "The Beginnings of Institutional Reform in Hungary," Soviet Studies 35 (July 1983), pp. 313-30. For a general description of austerity measures as an economic tool, see Andrew Crockett, "Stabilization Policies in Developing Countries," IMF Staff Papers 28 (March 1981), pp. 54-79. It must be noted that austerity measures in these countries differ from those imposed by the IMF on the Third World. First, these measures involve primarily a stabilization, not in most cases a decline in per capita income in the Eastern bloc. Second, the social wage is left intact, while pressures increase to work more for the same remuneration. In other words, austerity policy in these countries is not as austere as it has been elsewhere. This is because of Soviet aid, because of the ways in which fusion makes a tie between economic austerity and political protest highly likely, and, finally, because these countries, unlike the Third World periphery, are considerably less trade-dependent and much closer to an autarchic economic structure. All this explains, as well, why Eastern Europe could prune so much of the region's external debt-a reduction of $\$ 8$ billion in 1982 and $\$ 6.6$ billion in 1983 -and could slash imports from the West by $16 \%$ in 1982. See "Curtain Call." 
TABLE 8. Total terms of trade $(1975=100)$

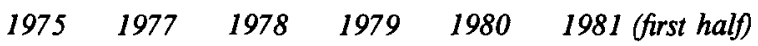

Centrally Planned

Economies,

Soviet Bloc

(19)

\begin{tabular}{lrrrrrr} 
Soviet Bloc & 100 & 104 & 106 & 109 & 110 & 113 \\
Eastern Europes & 100 & 98 & 99 & 97 & 95 & 93 \\
Soviet Union & 100 & 113 & 115 & 126 & 131 & 143 \\
\hline
\end{tabular}

a. When these figures are broken down by country, it is clear that while Poland's terms of trade improved somewhat over the 1970s (with 1976 the high point), the rest of the bloc states showed clear deterioration (with Hungary the extreme case). See Paul Marer, "Economic Performance and Prospects on Eastern Europe: Analytical Summary and Interpretation of Findings," in JEC, East European Economic Assessment: Part II (Washington, D.C., 1981), Chart 9, p. 51.

Source. United Nations, Economic Survey of Europe, vol. 33 (New York, 1981), p. 1.6.

For the Soviet economy, the economic dislocations in Eastern Europe led to a number of contradictions. By the end of the 1970s the Soviet Union had in a sense the worst of all worlds. The Soviets functioned as a periphery economy but enjoyed few of the benefits associated with that role. They were, for example, unable to "capitalize" on primary product strength during a period of high demand for such products. The Soviets also functioned as a core economy within the region but again enjoyed few of the associated benefits. Because of Eastern European economic problems, for instance, they were unable to convert economic dominance into international political and economic leverage. ${ }^{62}$

Eastern European demands increased and Western bankers became more powerful because these economies opened up to the West on the eve of a global recession. Eastern Europe had to be helped, because severe disruptions in intrabloc trade would hurt the Soviets. The tie between growth and stability in the client states meant that domestic stringency might lead to political instability in the satellites, and perhaps in the Soviet Union as well. Moreover, bankruptcy in any country of the bloc would close Western markets to the entire bloc, including the much stronger Soviet economy.

That final point gave Western bankers leverage. The Soviet Union needed Western trade and capital. But one default would in effect return the whole bloc to autarchy, ${ }^{63}$ which would create, because of bloc integration, a serious

62. For example, almost $90 \%$ of Soviet imports from West Germany-their largest trade partner in the West-are manufactured goods and high-technology items, most of which are unavailable in the East or of poorer quality. See Flora Lewis, "Split among Allies Runs Deeper than Sanctions," New York Times, 3 January 1982, and Steven Rosefielde, "Comparative Advantage and the Evolving Pattern of Soviet International Commodity Specialization, 1950-1973," in Rosefielde, Economic Welfare, pp. 185-222.

63. Indeed, the Soviets were in early 1982 denied a loan by the West Germans that would normally have been routine. At the same time, of course, the Soviets had several sources of strength in bargaining as well, albeit weak ones. One is the necessity of the banks admitting overexposure, another is the dearth of assets available in the West for seizure if bankruptcy were to occur. 
recession throughout the region. Recession in turn would lead to more pressures on the Soviet Union, either to bail out her clients or else risk the political disintegration of the empire. As a result, the economic and the political, the domestic and the foreign interests of the Soviet Union would be severely undermined. The regional hierarchical system replaced the normal "debt regime" that governed transactions between Western bankers and governments, on the one hand, and Turkey, Jamaica, Zaire, and the like, on the other ${ }^{64}$ This "debt regime" was unusually effective precisely because of Soviet strength and because one default would lead to a bloc-wide freezeout-an outcome against the interests of the entire bloc. ${ }^{65}$

Hence the Soviets had little choice but to aid their allies, through continued trade subsidies and explicit subsidies as well, and through pressure on more solvent states to help shoulder the burdens. As a result, Eastern European dependence on the Soviet Union for markets and basic commodities increased. Indeed, this trend extended to Romania and Yugoslavia, both of which came back to the fold at least insofar as trade was concerned. Soviet aid in the form of trade subsidies and positive trade balance increased, the bloc was forced to endure severe disruptions in trade, and the hard-currency earnings capacity of the Soviet Union began to fall.

There was a high, but understandable, correlation between Eastern European debt to the West and debt to the East, but the Soviets forfeited the gains that usually come from deepening dependency relations. Core-periphery dynamics within a regional hierarchical system combined with some of the core-periphery dynamics within the global economy at a time of crisis and led, for the Soviet Union, to the worst of all possible outcomes: "double dependency" for Eastern Europe, the semiperipheralization of the entire bloc, and a sizable reduction for the Soviets in the gains from empire.

In the early 1970s it seemed rather reasonable to argue that capitalist and socialist economies needed each other, especially as they both faced lower growth (though for different reasons), and that global trade would expand in the 1970s as it had in the 1960s. The experience of the 1970s was quite different-protected markets in the West, energy crisis, an expansion of attractive and highly competitive markets and suppliers in the Third World, and Eastern Europe's failure to use economic reforms or trade with the West to improve on the efficiency of capital usage or the quality of items produced. As a result, all those decisions made in the early 1970s produced precisely the opposite of what had been expected. Opening up to the West resulted in more, not less, pressure for economic reforms and more, not less, political and economic dependence of Eastern Europe on the Soviet Union. It also

64. See Lipson, "International Organization."

65. The one constraint on Western banks was the difficulty, in lieu of any formal role for the IMF (except in the Romanian case), of forging cooperation. In the Polish case, the banks involved-over 500, and many of them small-had difficulty organizing and admitting their exposure. See Ortmeyer, "Poland's Foreign Debt." 
led to greater strains in intrabloc relations, because of domestic austerity measures and the escalating burden of Poland. It led to less, not more, economic flexibility, because of the tug-of-war between external and internal demands over the diminishing surplus. It led to lower, not higher, Soviet and Eastern European economic growth. Finally, it led to serious challenges both to Party control over the polity as well as the economy in Eastern Europe and to Soviet control, or at least the benefits of that control, over the region. Dealing with capitalism in crisis, rather than "plugging up" holes, served "to stretch the system at its most sensitive points."

The Polish crisis is, of course, an extreme but illuminating case in point. While precise figures are hard to come by, it appears that by 1981 Poland owed Western governments and banks about $\$ 27$ billion. This burden was enormous: $\$ 27$ billion translates into a debt of about $\$ 770$ per capita, a debtservice ratio for 1981 of about 105 , and a ratio of total debt to export earnings of more than 400 percent (assuming export earnings in 1981 of about $\$ 6$ billion). By mid-1982 it was clear that the Poles could not pay the interest, let alone the principal, due in 1982, and a substantial rescheduling was arranged among the five hundred banks and numerous Western governments involved. The Polish economy was and is in a shambles. It is burdened by severe debts and in a structural sense cannot do much about it. Not only are few items available for export to the West but the country depends on imports for food, raw material, and energy, its planned economy is unusually inflexible and there is political stalemate between the Party and Solidarity.

The impact of debt on the domestic political economy of Poland and the whole region has been enormous. Shortages throughout the bloc have increased because of distortions in trade within the CMEA and with the West. The cost of living throughout the bloc has increased as well, because of the effects of domestic austerity measures. Moreover, the trend toward greater income inequality throughout the bloc is likely to continue, for two reasons. First, state pressures on the countryside and the factories to hold down labor costs will continue to increase. Second, the class-differentiated impact of budgetary and investment cutbacks funnels money into the most "productive" economic sectors and reduces, as far as is politically feasible, state subsidies for such basic goods as foodstuffs and housing.

The alliance of the early 1970s between "Western bankers and Polish housewives" necessarily led by the late 1970 s to the dropping of one member of that coalition-Polish housewives. While the pursuit of regime interests in combination with "lax Western credit was the creator of Solidarity," it was also "its executioner." ${ }^{67}$ Bankers wanted a reassertion of state control over consumption and over payment of the external debt in Poland. Their

66. Alex Pravda, "East-West Interdependence and the Social Compact in Eastern Europe," in Bornstein et al., East-West Relations, p. 184.

67. "Now Russia Asks for Time to Pay," Economist, 6 February 1982, p. 81. 
interests intersected with Soviet interests in Poland and the interests of the Polish elite in reinstating central control over the distribution of power and the rapidly diminishing economic surplus. There were "common interests between East and West in a rescue plan for the Polish economy." 68

The debt crisis had created what were from the perspective of global politics strange bedfellows, but from the perspective of global economics the alliance was not so much strange as it was familiar. It was an alliance between the capitalist core and the periphery's core-that is, a form of comprador collusion. But in this case none of the parties gained much from what was (from an economic and therefore political perspective) a necessary but not a terribly productive alliance. Western bankers gained little hope of recouping their money, the Soviet Union added to its financial and political burdens, the Polish Party lost its limited domestic support and became more dependent on the Soviet Union, and Polish workers lost political and purchasing power. The bloc as a whole, because of fusion, their derivative structures, and integrated trade, faced the possibility of economic and perhaps political bankruptcy.

\section{Conclusions}

Soviet relations with the empire in Eastern Europe have experienced a number of ironic developments over the past two decades. First, the Soviets established political and economic dominance in the region by creating derivative regimes headed by externally dependent elites; as a result, the Soviet role within the bloc has eventually evolved from one of coercion to one of captivity. The rubles expended to hold the bloc together were not just a serious drain on the Soviet economy. They were also spent without any guarantee of achieving their stated objectives, that is, enhancing the political and economic solvency of the region. The Soviets faced an intractable dilemma. The absence of Soviet aid would mean certain political instability and economic deterioration throughout the system, which would harm the Soviet economy, perhaps undercut Soviet domestic political stability, and certainly spell the end of the empire as East Germany, Poland, and Czechoslovakia faced mass unrest. On the other hand, Soviet aid merely whetted appetites in the periphery for more rubles and linked political stability even more closely to consumption and growth - and therefore to infusions of Soviet aid. Either way, the empire had become a burden, limiting rather than expanding Soviet power at home and abroad. The "distortions" in Eastern Europe brought on by Soviet control over the region, so often noted by Western analysts, were not without their

68. See Clyde Farnsworth, "Poles Ask Admittance to IMF," New York Times, 11 November 1981, and Farnsworth, "Washington Watch: IMF Team Visits Poland," New York Times, 21 December 1981 . 
costs to the Soviets as well. Indeed, it could be argued with equal force that by the early 1980 s it was the Soviet Union that was being distorted by the empire. $^{69}$

Second, elites in the client states had fused and centralized political and economic power and by necessity had based popular compliance on the delivery of tangible economic improvements. They thus made themselves politically vulnerable to economic downturns. Periodic recessions, moreover, became more common once these systems reached limits to extensively based growth and, more important, once the costs of too many demands and the veto power of groups offering capital or higher productivity had risen sharply. In fact, the constant manipulation of the economy for shortterm political gain, particularly in Poland, put such familiar practices in capitalist polyarchies to shame-an ironic outcome for systems free of electoral pressures. $^{70}$

Third, all these regimes went West to resolve internal contradictions and to buttress the power of the Party-state. In doing so, they managed to deepen domestic contradictions and to undermine, to some degree, the prevailing distribution of power. Rather than safeguarding socialism, they ended up "playing a functional role in the reproduction of capitalism." The end of economic autarchy opened up the possibility that political autarchy might end as well.

Finally, the Soviet Union "gained" from all this a position of mediating between the core-periphery dynamics within the bloc and those dynamics within the global capitalist system. As broker, however, the Soviets managed to bear all of the costs and few of the benefits. They lost money, access to Western markets, and economic as well as political control over the empire. The combination of the political and economic dependency of Eastern Europe, bloc integration through bilateral trade skewed toward the Soviet Union, sizable Soviet economic resources, and the Soviet Union's external position as regional hegemon and global power proved to be an unfortunate combination of strengths.

The dynamics of a regional hierarchical system and the dynamics of the world capitalist system in economic recession led to the semiperipheralization of the Soviet bloc in the global economy. Because of the structure of Stalinism in the client states, these dynamics led as well to the development, most notably in Poland, of Janus-faced elites unable to please domestic or foreign

69. Contrast these arguments with those emphasizing Eastern Europe's distortions. See Arpad Abonyi and Ivan Sylvain, "CMEA Integration and Policy Options for Eastern Europe: A Development Strategy for Dependent States," Journal of Common Market Studies 16 (December 1977), pp. 132-54, and Christopher Jones, "Soviet Hegemony in Eastern Europe: The Dynamics of Political Autonomy and Military Intervention," in Hoffman and Fleron, Conduct of Soviet Foreign Policy, pp. 559-82.

70. For the Western case, see Edward Tufte, Political Control of the Economy (Princeton: Princeton University Press, 1979).

71. Chase-Dunn, "Socialist States," p. 513. 
clienteles and subject to the constraints of "double" dependency. Finally, for the Soviet Union, all this led to a widening gap between policies resonant with the maintenance of empire and policies resonant with goals that underlay the logic of empire: in particular, the maximization of domestic economic growth, domestic stability, and secure borders. By the early 1980 s dominance over Eastern Europe undermined rather than extended Soviet interests at home and, to some degree, abroad as well. Indeed, the domestic and the foreign goals of empire were at increasing variance. 